\title{
Price-Setting Behaviour in Switzerland: Evidence from CPI Micro Data
}

\author{
Daniel KaUfmanN*
}

JEL-Classification: E31, D40

Keywords: CPI data, pricesetting, frequency of price changes, nominal price rigidity, timedependent pricing, state-dependent pricing.

\section{Introduction}

In recent years, macroeconomists have reemphasised the empirical observation that individual prices remain fixed over a substantial period of time. A large literature has emerged that studies the effect of monetary policy on inflation and output using dynamic stochastic general equilibrium models with nominal price stickiness. These models are used as a tool to analyse monetary policy and to produce forecasts. Researchers working with them must have an idea of how long time spells between price adjustments actually are and whether or not they are affected by the state of the economy. The latter question is related to the two forms of modelling price-setting behaviour which currently dominate the field: Time-Dependent Pricing (TDP) and State-Dependent Pricing (SDP). Calvo (1983) and Taylor (1980) propose models of TDP, Dotsey, King, and WoLMAN (1999), among others, of SDP. With SDP, the frequency of price adjustment depends on the state of the economy, whereas with TDP, the adjustment process is exogenous.

The empirical literature on nominal price stickiness has generally taken two directions. The first group of studies is based on surveys. In the questionnaires,

* Swiss National Bank, Economic Analysis, P.O. Box, CH-8022 Zurich, Switzerland. Phone: +41 (0)4463134 51. E-mail: daniel.kaufmann@snb.ch. The author would like to thank Marco Huwiler, Sarah Lein, Barbara Rudolf, Mathias Zurlinden, two anonymous referees, and participants of the YSEM meeting 2008 in Bern and of the SSES annual meeting 2008 in Lausanne for helpful discussions and comments. He would also like to thank the staff of the Prices Section at the Federal Statistical Office for valuable help with the data. All remaining errors are those of the author. The views expressed in this paper are those of the author and not necessarily those of the Swiss National Bank. 
firms are asked how often and why they adjust prices. In most cases, they are also confronted with explanations of price stickiness to assess the relevance of different theories. Examples are BLINDER et al. (1998) for the US or the studies conducted by researchers from the European Central Bank (ECB) as part of the so-called Inflation Persistence Network (IPN) (e.g. Fabiani et al., 2005). For Switzerland, ZurLinden (2007) has summarised an interview study conducted by the Swiss National Bank's delegates for regional economic contacts. In addition, there are survey studies focusing on Swiss export prices by Fischer, LUTZ and WäLti (2007) and on prices in the manufacturing sector by RUPPRECHT (2007).

Results from survey studies may be doubted on the grounds that what people do is not always what they say they do. For this reason, survey studies are not a complete substitute for an analysis of market price data. Such an analysis is the focus of the second group of studies on price stickiness. These studies examine micro price data from large-scale firm-level surveys. Prominent examples of this literature are studies by Bils and KLENOw (2004), Klenow and KRYvtsov (2008), and Nakamura and Steinsson (2008), who examine micro data from the US consumer and producer price indices. Along the same lines, several papers have been written on European countries by researchers of the IPN. These studies were summarised by Altissimo, Ehrmann and Smets (2006) and Dhyne et al. (2006). However, no comparable study has been made for Switzerland so far. ${ }^{1}$

This paper attempts to fill the gap by examining the micro data from Switzerland's consumer price index (CPI). The data collected by the Federal Statistical Office (FSO) cover the period from 1993 to 2005. The questions addressed are the following: (i) How often do prices change? (ii) Are there differences across sectors and firm size? (iii) How large are price changes on average? (iv) Is there evidence in favour of downward nominal price rigidity?

In addition, the paper examines changes in price adjustment frequencies and changes in the size of price adjustments based on quarterly averages. Two more questions arise in this context: (v) Does information about future value-added tax (VAT) cost shocks affect price-setting behaviour immediately? (vi) How do changes in the economic environment, specifically changes in inflation, influence the frequency and size of price changes?

The remainder of this paper is structured as follows. Section 2 describes the data. Sections 3 and 4 present the results. Section 5 concludes.

1 Götte, Minsch and Tyran (2005) analyse Swiss micro data from 1977 to 1993 for restaurants. 


\section{Data}

The data used in this paper are price quotes of the individual products underlying the Swiss CPI. ${ }^{2}$ An individual product is defined as a good or service sold in a specific outlet in a given quantity and quality. The price quotes were collected by the FSO over the 1993-2005 period. This section describes the raw data and then summarises the sampling decisions.

\subsection{The FSO Price Data}

Most of the price quotes are registered locally at stores. This means that they are actual transaction prices, in contrast to list prices which may differ significantly from what the firm actually charges. The rest of the prices are gathered over the internet or reported directly to the FSO.

The price quotes are registered in fixed intervals for a range of individual products. Most prices are collected every quarter. There are some exceptions. Prices of most food and energy products, for example, are registered monthly. The reason is that prices of these products are expected to change more often. Prices of administered products, some industrial products and some services are collected half-yearly or yearly.

Most individual products cannot be observed over the whole sampling period. Either the firm stopped supplying the specific product, or the FSO dropped it from the sample. In the first instance, the FSO has two ways to proceed. The price series is continued with the price of a product of the same quality or with the price of a close substitute. In the second instance, if a product is rotated out of the sample, the series ends without replacement. To compensate for such losses, new individual products are monitored such that the number of price quotes stays roughly constant over time. All these replacement actions are indicated by different processing codes.

The FSO changed its methodology to construct the CPI in May 1993, May 2000 and December 2005. ${ }^{3}$ Since the May 2000 revision, the CPI structure follows the Classification of Individual Consumption According to Purpose (COICOP) displayed in Table 1. There are 12 main groups from food and nonalcoholic beverages to miscellaneous goods and services. ${ }^{4}$ Each main group is broken

2 Source: FSO; data collection for the Swiss CPI 1993-2005.

3 For more information on the methodology, see FSO (1993, 2000, 2006).

4 The terminology according to the United Nations' COICOP methodology is somewhat different to the one used in this paper. They refer to the first level as divisions, the second level as groups and the third level as classes. In this paper, the terminology of the FSO is applied. 
down into two levels of subgroups. Furthermore, the FSO defines elementary index items and survey items in order to categorise the price quotes in more detail. Elementary index items represent the lowest level of aggregation for which the FSO publishes price indices and expenditure weights.

Table 1: Structure of the CPI Data Set

\begin{tabular}{|c|c|c|}
\hline Category & COICOP & FSO \\
\hline Food and non-alcoholic beverages & 01 & MG \\
\hline Food & 01.1 & \\
\hline Bread and cereals & 01.1 .1 & \\
\hline Bread & & EII \\
\hline Whole-grain bread & & SI \\
\hline \multicolumn{3}{|l|}{$\ldots$} \\
\hline Alcoholic beverages, tobacco and narcotics & 02 & MG \\
\hline Clothing and footwear & 03 & MG \\
\hline Housing, water, electricity, gas and other fuels & 04 & MG \\
\hline Furnishings, household equipment and routine household maintenance & 05 & MG \\
\hline Health & 06 & MG \\
\hline Transport & 07 & MG \\
\hline Communication & 08 & MG \\
\hline Recreation and culture & 09 & MG \\
\hline Education & 10 & MG \\
\hline Restaurants and hotels & 11 & MG \\
\hline Miscellaneous goods and services & 12 & MG \\
\hline
\end{tabular}

Note: CPI categories according to COICOP and FSO classifications. MG: Main groups; EII: Elementary index items; SI: Survey items.

The May 2000 revision brought changes in the number and composition of the main groups. However, the survey items remained mostly the same and have simply been regrouped into the new structure of the CPI basket. More important changes associated with the May 2000 revision concern end-of-season sales prices. Before 2000, the data collectors had to ask the manager of a specific outlet, what the price would have been, if it were not reduced. After that, the transaction 
price was collected and marked with a sales flag. Finally, the FSO has collected the prices of some products more regularly since 2000 and 2001. This primarily concerns services and industrial products.

\subsection{Sampling Decisions}

The investigation takes place over the period from Q2 1993-Q4 2005. The beginning and the end of this period are determined by the two CPI revisions of May 1993 and December 2005. Due to the CPI revision of May 2000, the full period is split into two shorter periods: from Q2 1993 to Q1 2000 and from Q2 2000 to Q4 2005. All results presented in Section 3 are provided for these two periods.

The analysis is based on quarterly data. This implies that the maximum number of price changes per quarter is one for all products. If prices have been collected more frequently, this has been ignored. The monthly data are aggregated to quarterly frequency by choosing the last month of every quarter. ${ }^{5}$ Prices of half-yearly or yearly collected goods are excluded from the sample. That way we ensure that all prices are allowed to change once per quarter. At the same time, we systematically exclude prices that are unlikely to change very often, since this is the reason why the FSO collects them less frequently.

Some index items are excluded from the sample because they do not contain actual micro price data. In these cases, the FSO uses external data sources and then calculates an average price. Examples are public transport, pharmaceuticals, hospital services, medical services, postal services, telecommunication and rents. Similarly, the prices of administered products are excluded, for they are collected rarely and do not reflect market conditions.

Sales prices are excluded from the sample because they differ from normal price changes in various respects. In particular, they are temporary and generally expected to occur regularly. One way to identify sales prices is to use the sales indicator provided by the FSO. However, because the pricing decision of the firm could reflect both regular sales and a reoptimisation of prices in response to economic shocks, this indicator can be misleading. Price changes that are purely temporary have therefore been excluded; that is, prices that drop in one period and then return to their original value in the next. These temporary price

5 Another possibility would be to randomly choose one month per quarter. This, however, would make comparisons of quarterly averages over time difficult, since some price changes would be mechanically shifted one quarter into the future. 
changes account for $1.3 \%$ of all price changes in the first sample and $1.7 \%$ in the second sample. ${ }^{6}$

Finally, one has to decide how to treat price changes due to product turnover. This is not a problem if the FSO replaces a product directly, that is, if the quality is the same (as in the context of simple repackaging, for example). Consequently, they are treated like regular price changes. Replacements by close substitutes, however, are tricky because the price difference may reflect an unobserved difference in quality. In this case, the price change is counted when the frequency of price changes is calculated, but is ignored when the focus is on the size of price changes. Price changes due to product turnover account for $2.6 \%$ and $2.7 \%$ of all price changes in the two samples.

In Section 4, the focus is on quarterly changes of descriptive statistics. The data set used in this section contains only survey items for which price quotes are available throughout the full period from Q2 1993 to Q4 2005. Thus, results presented in Section 4 are based on a smaller data set than those presented in Section 3.

Table 2 summarises the effect of the sampling decisions on the number of observations. The original data set provided by the FSO includes almost 2.9 million quarterly observations in the first period (Q2 1993-Q1 2000) and 1.6 million observations in the second period (Q2 2000-Q4 2005). The number of observations used in the descriptive analysis in Section 3 amounts to $66.2 \%$ of the original data set in the first period and $95.2 \%$ in the second period. The index items included in the two samples account for $40.3 \%$ and $52.3 \%$ of the CPI. The significant difference in the share of discarded observations is due to the restriction that only those observations that are collected quarterly or more frequently are considered. Furthermore, there are significant differences among sectors. In the first period, for example, only $11.4 \%$ of the original observations from the services sector are used in the descriptive analysis. This may lead to an upward bias of the frequency statistics reported in Section 3, since most of the excluded product prices are those which the FSO collects less frequently because they are expected to change rarely. The number of observations used in the analysis in Section 4 is further reduced to $57.8 \%$ of the original data set in the first period and $68.4 \%$ of the original data set in the second period.

6 To examine whether the exclusion of temporary price changes affects the results, some key statistics are reported for the data set which includes these temporary price changes. 
Table 2: Sample Summary

\begin{tabular}{|c|c|c|c|c|c|}
\hline Category & $\%_{1}$ & $O_{1}$ & $W$ & $\%_{2}$ & $\mathrm{O}_{2}$ \\
\hline \multicolumn{6}{|c|}{ (a) Q2 1993-Q1 2000} \\
\hline Overall & 66.2 & $1,904,959$ & 40.3 & 57.8 & $1,663,485$ \\
\hline Processed food & 99.5 & 711,338 & 9.5 & 83.8 & 599,079 \\
\hline Unprocessed food & 100.0 & 386,879 & 4.9 & 83.5 & 322,978 \\
\hline Industrial products & 71.5 & 703,133 & 17.1 & 65.9 & 647,915 \\
\hline Energy & 57.7 & 16,323 & 2.8 & 51.8 & 14,648 \\
\hline Services & 11.4 & 87,286 & 6.0 & 10.3 & 78,865 \\
\hline \multicolumn{6}{|c|}{ (b) Q2 2000-Q4 2005} \\
\hline Overall & 95.2 & $1,492,348$ & 52.3 & 68.4 & $1,072,286$ \\
\hline Processed food & 99.1 & 358,284 & 8.9 & 91.6 & 330,996 \\
\hline Unprocessed food & 100.0 & 199,722 & 3.5 & 87.9 & 175,491 \\
\hline Industrial products & 99.2 & 678,800 & 20.3 & 71.1 & 486,615 \\
\hline Energy & 52.2 & 15,922 & 4.0 & 46.5 & 14,191 \\
\hline Services & 82.0 & 239,620 & 15.6 & 22.2 & 64,993 \\
\hline
\end{tabular}

Note: $\%_{1}$ : Price observations used in Section 3 as share in the original data set (\%); $\%_{2}$ : Price observations used in Section 4 as share in the original data set (\%); $O_{1}$ : Price observations used in Section 3; $\mathrm{O}_{2}$ : Price observations used in Section 4; W: Average CPI expenditure weight.

\section{Frequency and Size of Price Adjustments}

This section presents the main findings about price-setting behaviour in Switzerland based on a descriptive analysis. Most of the statistics are calculated at the elementary index item level and are then aggregated across sectors by taking an average or median, weighted by the corresponding expenditure weights. One exception are the groupings with respect to the outlet size, which are calculated at the level of the individual firm and then aggregated using an unweighted mean and median. 


\subsection{Are Prices Sticky?}

To examine whether prices are sticky, we can calculate the frequency of price changes. Let $f p c_{j}$ denote the average fraction of prices of index item $j$ which change in a given quarter. Given $f p c_{j}$, the median time spell between two consecutive price adjustments can be computed. Assuming that the duration of price spells follows an exponential distribution, the implied (median) duration, $d_{j}$, can be written as ${ }^{7}$

$$
d_{j}=\frac{\ln (0.5)}{\ln \left(1-f p c_{j}\right)} .
$$

Table 3 summarises the results for the aggregated frequency and duration statistics over the periods Q2 1993-Q1 2000 and Q2 2000-Q4 2005. The main results are given in the first row. We can see that from 2000 to 2005, an average of $23.4 \%$ of all prices have changed per quarter $(f p c)$. This implies an average duration of 4.6 quarters. The median frequency of price changes $\left(f p c_{m}\right)$ is lower at $13.8 \%$, implying a duration of 4.6 quarters. ${ }^{8}$ The results for $1993-2000$ are similar. The frequency of price changes amounts to $23.6 \%$ and $13.2 \%$ (median) and the implied duration to 5.0 and 4.8 quarters respectively.

As described in the data section, temporary price changes (sales) are excluded from the data set. The median frequency and implied duration based on data that include temporary price changes $\left(f p c_{m}^{s}, d_{m}^{s}\right)$ appear in the fifth and sixth column. As can be expected, the frequency is slightly higher (1.6 pp) in the two periods, and the duration lower (0.5 quarters).

Compared to studies on the euro area and the US, the price durations found for Switzerland are longer. For the euro area, Dhyne et al. (2006) obtain a median duration of 10.6 months over the 1996-2001 period. For the US, NAKAMURA and STEINSSON (2008) find a median duration of 11 months for 1998-2005, whereas

7 An exponential distribution of price durations implies a constant conditional probability that a price changes in a certain quarter given no change happened until then (i.e. the hazard rate $\alpha$ ). The unconditional probability that a price changes during a given quarter is $\mathrm{F}=1-\mathrm{e}^{-\alpha}$. Therefore, $\alpha=\ln (1-F)$. The mean duration is then calculated as $-1 / \ln (1-F)$ and the median duration as $\ln (0.5) / \ln (1-F)$.

8 The durations can also be computed directly from the spells between two consecutive price adjustments. For the total, we obtain an average duration of 4.5 (3.9) quarters and a median duration of 4.7 (4.1) quarters in the period Q2 1993-Q1 2000 (Q2 2000-Q4 2005). Since this approach raises issues such as left- and right-censoring of the data, the focus stays on the durations derived under the assumption of an exponential distribution of the price spells. 
Bils and Klenow (2004) find an even smaller median duration (4.3 months). The differences to the findings for Switzerland may reflect different sampling schemes. Alternatively, they may result from differences in structural factors of the economy, such as trend inflation, the degree of competition on the markets for goods and services, and the flexibility of the labour market.

Table 3: Frequency of Price Changes

\begin{tabular}{|c|c|c|c|c|c|c|}
\hline Category & $f p c_{m}$ & $d_{m}$ & $f p c$ & $d$ & $f p c_{m}^{s}$ & $d_{m}^{s}$ \\
\hline \multicolumn{7}{|c|}{ (a) Q2 1993-Q1 2000} \\
\hline Overall & 13.2 & 4.8 & 23.6 & 5.0 & 14.8 & 4.3 \\
\hline Processed food & 12.6 & 5.0 & 12.5 & 5.7 & 13.9 & 4.5 \\
\hline Unprocessed food & 41.8 & 1.1 & 40.5 & 1.9 & 44.5 & 1.0 \\
\hline Industrial products & 10.7 & 6.0 & 12.8 & 6.3 & 11.2 & 5.8 \\
\hline Energy & 78.4 & 0.4 & 83.3 & 0.4 & 80.5 & 0.4 \\
\hline Services & 19.5 & 1.6 & 30.0 & 4.7 & 19.7 & 1.5 \\
\hline Small outlets & 10.3 & 6.2 & 15.5 & 9.1 & 10.6 & 5.9 \\
\hline Medium outlets & 12.6 & 4.9 & 16.8 & 10.5 & 13.2 & 4.6 \\
\hline Large outlets & 22.2 & 2.6 & 31.7 & 4.4 & 23.6 & 2.4 \\
\hline \multicolumn{7}{|c|}{ (b) Q2 2000-Q4 2005} \\
\hline Overall & 13.8 & 4.6 & 23.4 & 4.6 & 15.4 & 4.1 \\
\hline Processed food & 12.2 & 5.3 & 12.5 & 5.6 & 14.4 & 4.4 \\
\hline Unprocessed food & 37.4 & 1.4 & 38.7 & 1.9 & 41.5 & 1.2 \\
\hline Industrial products & 14.4 & 4.4 & 20.1 & 4.5 & 17.0 & 3.7 \\
\hline Energy & 85.5 & 0.3 & 87.6 & 0.5 & 88.7 & 0.3 \\
\hline Services & 9.0 & 6.6 & 13.8 & 6.1 & 9.2 & 6.6 \\
\hline Small outlets & 9.5 & 5.1 & 16.5 & 7.8 & 10.0 & 4.8 \\
\hline Medium outlets & 13.0 & 3.7 & 15.3 & 5.8 & 13.6 & 3.5 \\
\hline Large outlets & 18.8 & 2.9 & 29.2 & 5.1 & 19.9 & 2.7 \\
\hline
\end{tabular}

Note: $f p c$ : Frequency of price changes (\%); $d$ : Implied duration (quarters); $m$ : Median; $s$ : Including sales. 


\subsection{Does Price Stickiness Differ Between Sectors or Outlet Characteristics?}

This section examines whether the price-setting measures differ among sectors and between outlets of different size. Results on prices of products broken down into five sectorial groups are shown in Table 3, rows 2-6.' Taking the median durations for the 2000-2005 period as the chief indicator, we can make out a cluster of groups at the upper end with $d_{m}$ ranging from 4.4 to 6.6 quarters (industrial products, processed food and services). Energy, with $d_{m}=0.3$ quarters, defines the other pole. Unprocessed food takes the middle ground ( $d_{m}=1.4$ quarters).

These results suggest that prices of consumer goods are changed more frequently when input prices are volatile. Energy, for example, contains mostly products based on crude oil which is traded on the world market. The price of crude oil responds promptly to market conditions, and changes in the price of crude oil are transmitted rapidly to the price of fuels or heating oil. In the service sector, on the other hand, the largest input factor is labour, the price of which does not vary greatly in the short term. Wages are sticky due to long-term wage contracts that are not likely to change more than once per year. The difference between unprocessed food and processed food gives another example for the role played by factor shares in the production process. As the labour input is larger in processed food, the corresponding consumer prices may be expected to be stickier. This is corroborated by the results in Table 3, indicating that the median duration equals 5.3 quarters for processed food and 1.4 quarters for unprocessed food. The results for the 1993-2000 period are similar for energy, unprocessed food and processed food. Differences between the two periods are apparent in the service sector and for industrial products. This stems from the fact, that for these sectors, a relatively large share of the price quotes was discarded in the first sample. The frequency in the services sector is especially biased upwards due to the exclusion of rarely collected items of the CPI.

Next, the products are grouped according to the size of the outlet where they are on offer. Table 3, rows 7-9, show the corresponding results for small outlets, medium outlets and large outlets. ${ }^{10}$ The results over the 2000-2005 period suggest that the median price duration of products offered by small outlets ( 5.1 quarters)

9 This grouping takes place at the index item level. The allocation is according to the Eurostat's classification of individual consumption by purpose adapted to the needs of harmonised indices of consumer prices. For more information see http://ec.europa.eu/eurostat/ramon.

10 This information was provided by the FSO. The FSO defines large outlets as country-wide operative firms, medium outlets as regional firms with only few branches, and small outlets as locally operative firms. 
is larger than that of products offered by medium or large outlets (3.7 and 2.9 quarters respectively). The results for the 1993-2000 period also suggest that large firms change prices more often.

Taking the results at face value, it can be argued that long-term customer relations play a more important role for small outlets than for large outlets. Thus, small outlets are likely to lose more when they raise prices and thereby risk impairing customer relations. Another explanation is that large outlets may have more information on market conditions than small ones. Thus, they respond more rapidly and more frequently to changes in market conditions than small outlets.

\subsection{How Large Are Price Changes?}

The overall inflation rate can be decomposed into two parts. How many prices are adjusted, and by how much? Whereas the focus was on the first question in Sections 3.1 and 3.2, this section focuses on the second question. To examine the size of price changes, let the percentage change in prices of index item $j$ be defined as

$$
\text { Size }_{j}=\frac{\sum_{i=1}^{n_{j}} \sum_{t=2}^{\tau_{i}} c_{j i t}\left(\frac{\left|p_{j i t}-p_{j i, t-1}\right|}{p_{j i, t-1}}\right)}{\sum_{i=1}^{n_{j}} \sum_{t=2}^{\tau_{i}} c_{j i t}},
$$

where $p_{j i t}$ denotes the level of a price quote, $c_{j i t} \in\{0,1\}$ indicates whether a price change has occurred or not, $i$ indexes individual products, $j$ index items, and $t$ time. This measure is calculated for the total and separately for price increases and price decreases $\left(\right.$ Size $_{j}^{+}$, Size $\left._{j}^{-}\right)$.

The results summarised in Table 4 show that the median absolute size of a price change amounts to $9.4 \%$ over the $2000-2005$ period, whereas the mean absolute size is higher at $11.6 \%$. Results for the period 1993-2000 are similar. Given the low and stable CPI inflation observed during these two periods, the size of the price changes may come as a surprise. However, the results are consistent with the view that price adjustments are costly. The literature on menu costs suggests that when firms decide on a price adjustment, they do this in an optimising way by balancing the fixed cost of a price adjustment against the effect of the new price on the discounted value of expected future returns. In the absence of price 
Table 4: Size of Price Changes

\begin{tabular}{|c|c|c|c|c|c|}
\hline Category & Size $_{m}$ & Size & $S_{i z e^{+}}$ & $S i z e^{-}$ & Size $_{m}^{s}$ \\
\hline \multicolumn{6}{|c|}{ (a) Q2 1993-Q1 2000} \\
\hline Overall & 9.0 & 9.8 & 9.8 & 10.3 & 9.7 \\
\hline Processed food & 8.9 & 8.7 & 8.5 & 9.2 & 10.2 \\
\hline Unprocessed food & 15.2 & 18.4 & 20.9 & 15.8 & 15.3 \\
\hline Industrial products & 9.0 & 8.4 & 7.6 & 10.1 & 9.2 \\
\hline Energy & 2.7 & 4.5 & 5.6 & 3.3 & 2.7 \\
\hline Services & 8.1 & 11.0 & 11.1 & 11.3 & 8.3 \\
\hline \multicolumn{6}{|c|}{ (b) Q2 2000-Q4 2005} \\
\hline Overall & 9.4 & 11.6 & 12.1 & 11.6 & 12.8 \\
\hline Processed food & 10.6 & 10.3 & 9.9 & 11.3 & 13.5 \\
\hline Unprocessed food & 14.6 & 19.2 & 21.6 & 16.8 & 17.5 \\
\hline Industrial products & 10.4 & 13.5 & 14.2 & 13.3 & 16.1 \\
\hline Energy & 4.8 & 7.0 & 7.9 & 5.9 & 4.9 \\
\hline Services & 7.9 & 9.2 & 9.6 & 9.9 & 11.0 \\
\hline
\end{tabular}

Note: Size: Size of price changes (\%); m: Median; s: Including sales.

adjustment costs, one would expect that firms revise their prices continuously and thus by rather small amounts.

Turning to the five sectors, it can be noted that the median size of price changes in the 2000-2005 period ranges from $14.6 \%$ for unprocessed food to $4.8 \%$ for energy. Most sectors illustrate the trade-off between frequency and size of price adjustments. The energy sector is characterised by relatively frequent price adjustments (see Section 3.2); the price adjustments, however, are relatively small. Other sectors, with less frequent price adjustments, exhibit larger price changes. The two sectors that do not line up in this way are unprocessed food and services. Both the frequency and the size of price adjustments are high for unprocessed food and low for services.

The comparison between the size of price increases and decreases provides some interesting insights. Price increases are about as sizeable as decreases in the overall sample. There are, however, substantial differences in various sectors. Price decreases are larger than increases in processed food and services. Note that these are the product categories with less frequent price changes than in the 
overall sample, and as we will see below, with less frequent price decreases. On the other hand, the size of price decreases is lower in sectors where price changes (specifically price decreases) occur frequently.

If the temporary price changes reflect price changes due to sales, it can be expected that they are relatively large in size. This is confirmed by the median size, which is generally higher if temporary price changes are not excluded from the data set $\left(\right.$ Size $\left._{m}^{s}\right)$.

\subsection{Are Prices Downward Rigid?}

It is often argued that monetary policy should target a rate of inflation above zero in the presence of nominal downward rigidity of prices. Such a target, it is said, would facilitate relative price adjustments and therefore lead to more efficient market outcomes. Table 5 takes a look at the frequency of price increases and decreases. It shows these frequencies $\left(f p c^{+}, f p c^{-}\right)$and the share of price increases and decreases in total price changes $\left(f p c_{\%}^{+}, f p c_{\%}^{-}\right)$.

Table 5: Frequency of Price Increases and Decreases

\begin{tabular}{lcccc}
\hline Category & $f p c^{+}$ & $f p c^{-}$ & $f p c_{\%}^{+}$ & $f p c_{\%}^{-}$ \\
\hline Overall & \multicolumn{2}{c}{ (a) Q2 } & 1993-Q1 2000 & \\
\hline Processed food & 13.2 & 10.3 & 56.2 & 43.8 \\
\hline Unprocessed food & 6.7 & 5.9 & 53.1 & 46.9 \\
Industrial products & 21.4 & 19.1 & 52.9 & 47.1 \\
Energy & 8.1 & 4.7 & 63.6 & 36.4 \\
Services & 40.7 & 42.6 & 48.8 & 51.2 \\
\hline & 18.6 & 11.4 & 62.2 & 37.8 \\
Overall & $(\mathrm{b})$ Q2 $2000-\mathrm{Q} 42005$ & & \\
\hline Processed food & 13.7 & 9.6 & 58.7 & 41.3 \\
Unprocessed food & 8.2 & 4.4 & 65.2 & 34.8 \\
Industrial products & 21.4 & 17.2 & 55.4 & 44.6 \\
Energy & 11.1 & 9.0 & 55.2 & 44.8 \\
Services & 47.2 & 40.4 & 53.9 & 46.1 \\
\hline
\end{tabular}

Note: $f p c^{+}, f p c^{-}$: Positive, negative $f p c(\%) ; f p c_{\%}$ : Relative $f p c(\%)$. 
The results indicate that, in the $2000-2005$ period, $41.3 \%$ of all price changes were price decreases. In the 1993-2000 period, this share is slightly higher at $43.8 \%$. It is not surprising that price increases are more frequent than price decreases because the average CPI inflation rate was positive over these two periods. Nevertheless, the results make it clear that, despite positive overall inflation, a substantial share of all price changes were price decreases. Turning to the results for the six sectors, one notes that the share of price decreases varies a great deal across sectors. In the unprocessed food, industrial products and energy sectors, price decreases are almost as frequent as price increases. For services, however, price decreases are substantially less frequent than price increases. These findings are similar to those reported by studies on the euro area and the United States. Working with data from the euro area, DHYNE et al. (2006) find a ratio between price increases and decreases of $58 \%$ to $42 \%$. In the service sector, they find a share of price decreases in total price changes of $20 \%$. For the US, NakamUra and STEInsson (2008) report a share of price decreases of $35.2 \%$. For services (excluding travel), this share is down to $21 \%$.

With positive CPI inflation, the distribution of price changes provides a more informative indicator of nominal rigidities than the share of price decreases in total price changes. Figure 1 (panels a and b) displays the distributions of percentage changes in prices in 1994 and 2004. ${ }^{11}$ In both periods, small price increases (up to $5 \%$ ) occur most frequently. However, small price decreases occur quite regularly, too. This is in line with the moderate inflation rates in Switzerland both in 1994 and 2004 (0.85\%, 0.80\%). Although small price decreases are less frequent than small price increases, there is no indication for a substantial asymmetry in the distribution. In Mexican data, for example, GaGNON (2007) found much more pronounced asymmetries in the distribution of price changes.

Figure 1 further displays the distribution of percentage changes in prices for selected sectors. The general characteristics of the overall histogram prevail in the histograms for processed food (panels $\mathrm{c}$ and d) and industrial products (panels e and f). Although small price increases occur most frequently, the asymmetry of the distribution is small. The histograms for unprocessed food (panels $\mathrm{g}$ and $\mathrm{h}$ ) differ substantially from those for the overall economy. First, small price increases are only slightly less frequent than small price decreases (up to 10\%). Second, the distributions feature fatter tails. This may reflect the fact that the prices of unprocessed food are strongly affected by seasonal patterns and that they are not

11 All histograms are restricted to show price changes from $-100 \%$ to $+100 \%$. There are very few price changes beyond this range. 
Figure 1: Histograms of the Size of Price Changes
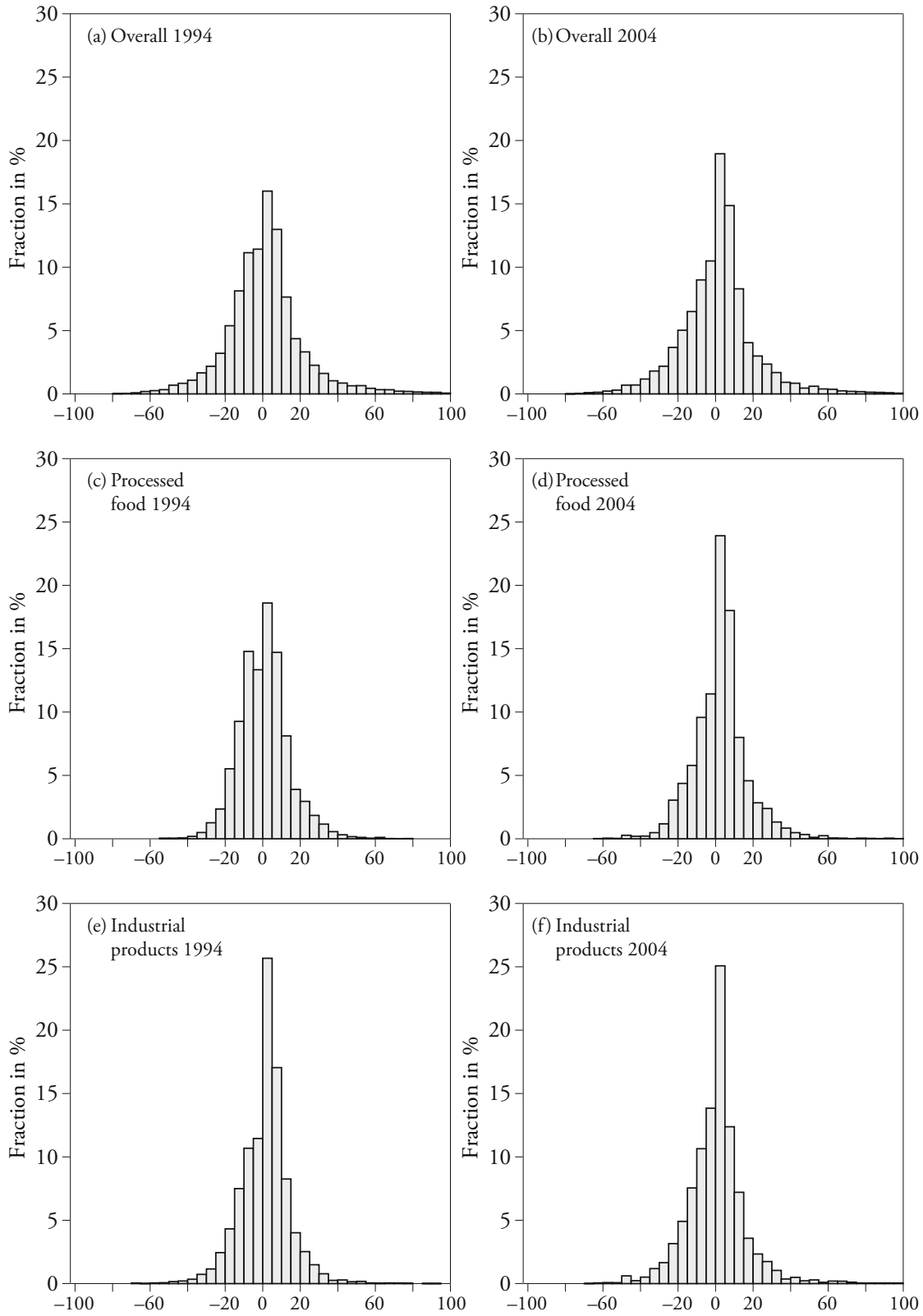
Figure 1 continued
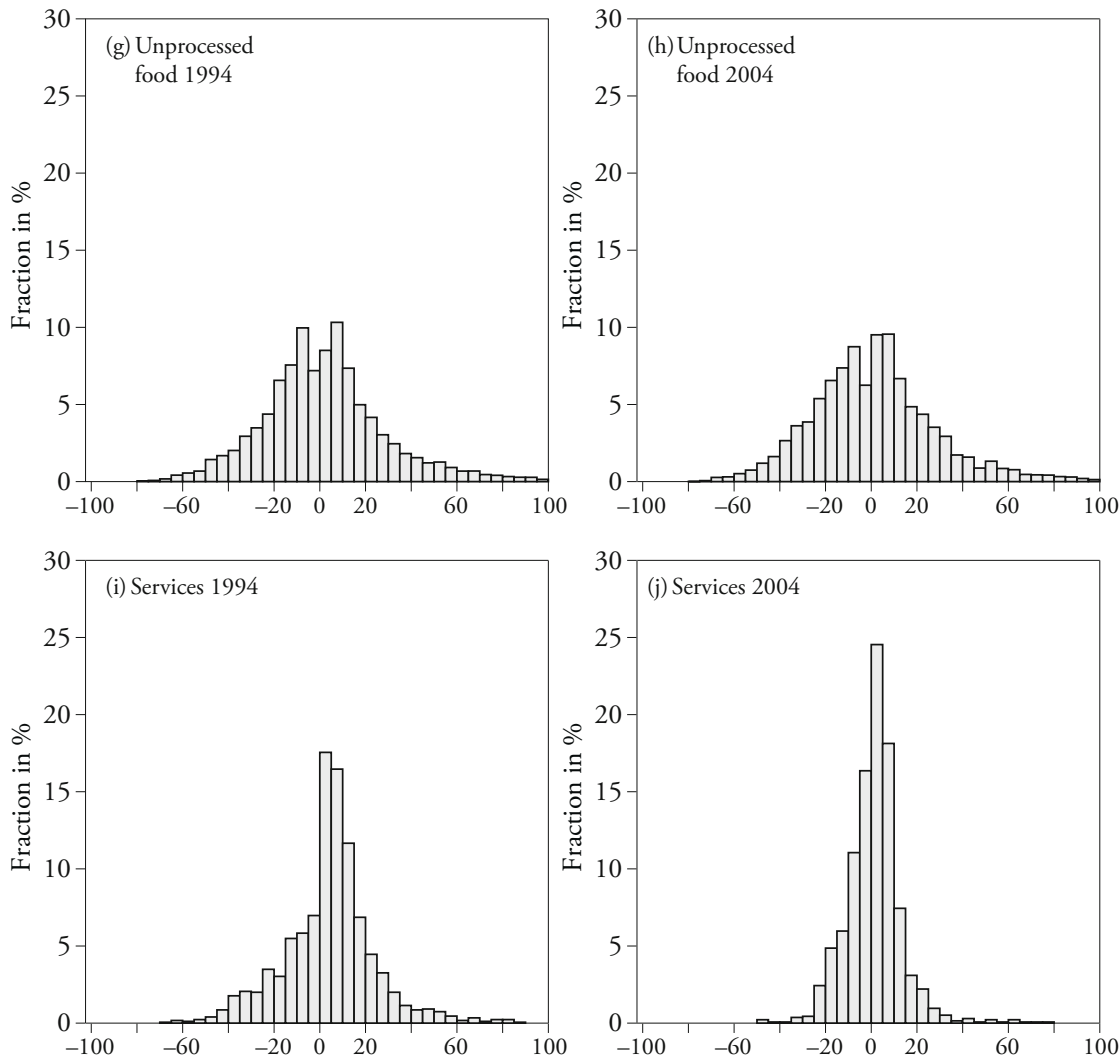

storable. Although price changes occur frequently they are rather large in size. The histogram for services differs compared to the other cases. In 1994, only about $12 \%$ of all price changes were decreases with a size up to $10 \%$ (panel i) compared to about $22 \%$ in the overall sample. At the same time, however, price increases with a size up to $10 \%$ were about as frequent as in the overall sample. Interestingly, the asymmetry of price changes in the service sector has become less pronounced in recent years. In 2004, small price decreases accounted for over 25\% of all price changes (panel j).

To some extent, differences among sectors reflect differences in the sectorial inflation rate. Prices in the service sector rose by $1.4 \%$ on average over the 
1993-2005 period, whereas prices of goods rose at an average rate of just $0.6 \%{ }^{12}$ Another factor is the varying share of labour input in the production process. As noted above, the service sector is widely regarded as a sector with a relatively high labour share in production. As wages exhibit some degree of nominal downward rigidity, this could translate into downward rigid consumer prices. Evidence for downward rigidity of nominal wages in Switzerland is provided by FEHR and GöTte (2005).

\section{Factors Affecting Price-Setting Behaviour}

This section looks at how the quarterly frequency $\left(f p c_{t}\right)$ and the size $\left(S_{i z e}\right)$ of price changes have evolved over the 1993-2005 period and what factors have affected price-setting behaviour. Compared to Section 3, the data set is further reduced in order to create a consistent sample over the 1993-2005 period (see Section 2.2). Moreover, the statistics are calculated as unweighted means in order to prevent effects from changes in the CPI expenditure weights.

Empirical evidence for the effect of economic factors on price adjustment frequencies is provided by Fougère, Le Bihan and Sevestre (2007) and Dias, Marques, and Santos Silva (2007), among others. They show that shifts in the level of inflation and VAT rate hikes increase the probability that a firm changes the price of its product. In a similar set-up, Rupprecht (2007) finds in survey data for Switzerland that macroeconomic factors as well as firm specific characteristics influence price-setting behaviour.

\subsection{Price-Setting Statistics over Time}

Figure 2 panel (a) shows the quarterly $f p c_{t}$ from 1993 to 2005. Panel (b) displays the $f p c_{t}$ split up into price increases and decreases. The average size of positive and negative price changes $\left(\right.$ Size $_{t}^{+}$, Size $\left._{t}^{-}\right)$is displayed in Figure 3. We can see that the frequency of price changes varies a great deal during that period. The size of the price changes also exhibits some variability. The general trend is flat for all series.

It is interesting to view the patterns in Figures 2 and 3 against the backdrop of the implications of TDP and SDP models. TDP models assume that the price adjustment frequency is given exogenously. In CALvo (1983), for example, the firm

12 The inflation rates refer to services including health and administered products. 
Figure 2: Frequency of Price Changes

(a) Overall frequency and inflation

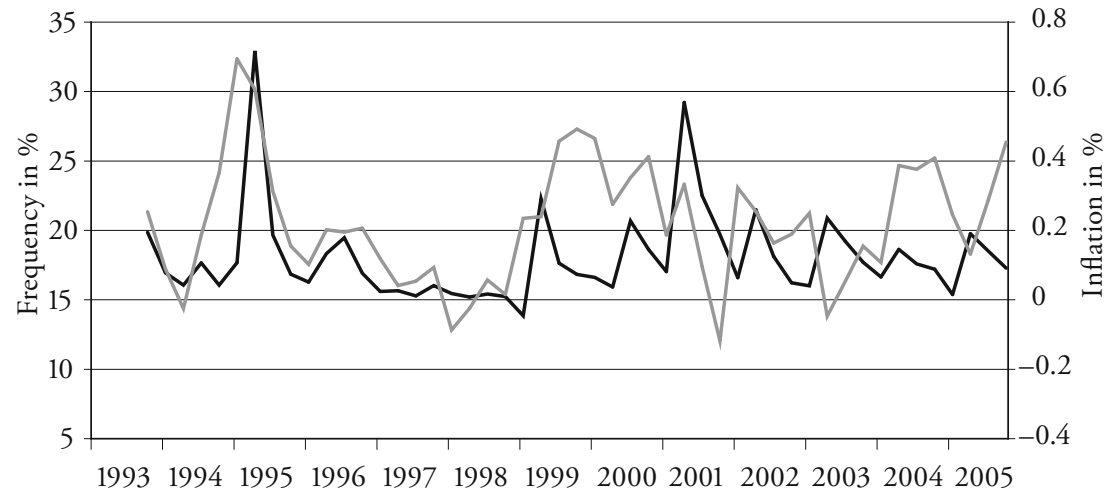

- Overall frequency - Inflation (q/q, rhs)

(b) Frequency of price increases and decreases

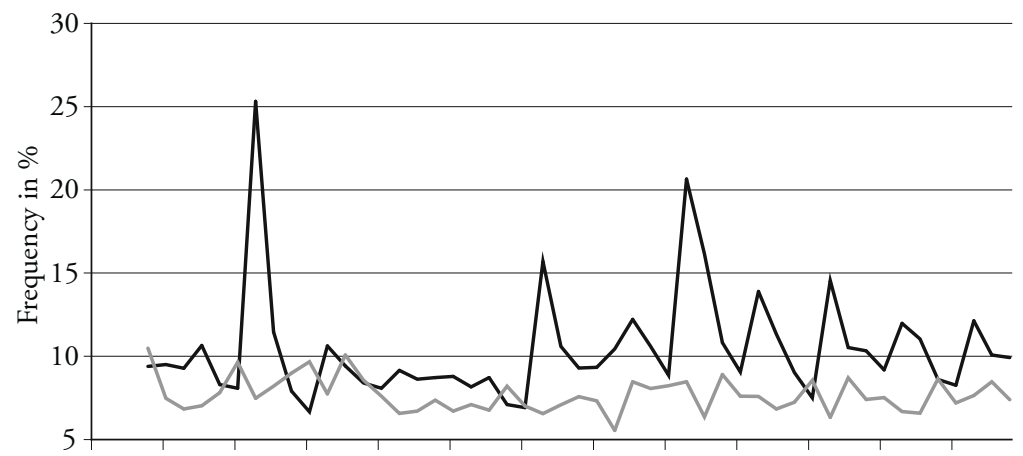

1993199419951996199719981999200020012002200320042005

- Positive changes — Negative changes

receives a stochastic signal each period about whether or not it is allowed to adjust its price. The signal occurs at some exogenously assumed constant probability. Hence, the firm decides only about the size of the price adjustment, not about the timing. Another example of a TDP model is TAYLOR (1980), where prices are sticky due to multi-period nominal contracts of fixed intervals. A common feature of these models is that the share of firms that adjust prices is invariant to unexpected 
changes in the economic environment. In an SDP model, firms decide on both the timing and the size of a price change. Assuming stochastic costs of price adjustment, the firm weighs the realisation of the adjustment cost against the effect of adjusting its price on the discounted flow of expected future earnings. So the key implication of SDP models is that firms react to economic shocks by changing the price adjustment frequency as well as the size of the price adjustment. Dotsey, KING, and Wolman (1999) is a prominent example of this type of model.

Figure 3: Size of Price Changes

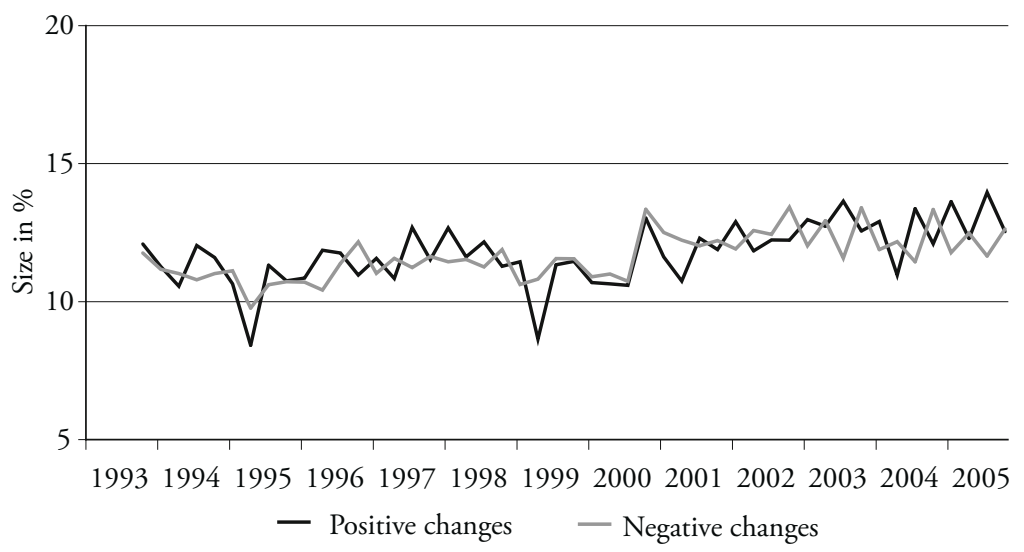

The substantial variability of $f p c_{t}$ is consistent with the SDP models. It is not consistent with the TDP model if we exclude the extreme case where all changes in the economic environment are expected. Because both models predict the size of price changes to vary over time, the variability of the size of price changes displayed in Figure 3 is consistent with both models.

\subsection{Effect of Changes in Inflation and VAT Rates}

Changes in the rate of inflation are a prominent candidate for a factor affecting the frequency of price changes. SDP models suggest that the frequency of price changes increases with rising inflation. Working with data on Mexico, GAGNON (2007) found strong evidence in support of such an effect. In Figure 2, quarteron-quarter percentage changes in Switzerland's CPI are shown together with 
the $f p c_{t}{ }^{13}$ Unfortunately, the changes in the rate of inflation have been modest throughout the period under review. Moreover, the picture is blurred by the VAT rate changes in 1995, 1999 and 2001, and their effects on the rate of inflation. Nevertheless, there is a connection between the $f p c_{t}$ and the inflation rates. We can spot a phase with falling inflation rates ending in 1998. From 1999 onwards, the inflation rates first moves higher and then sideways until 2005. In this second phase, the average quarter-on-quarter rate of inflation is slightly higher $(0.25 \%)$ than during the 1994-1999 period (0.16\%). This inflation pattern is roughly in line with the medium-term changes in the $f p c_{t}$. Abstracting from the three spikes, we notice a slight decline ending in 1999, followed by higher $f p c_{t}$ levels from 1999 onwards. In addition, we can see that the frequency of price increases $\left(f p c_{t}^{+}\right)$in panel (b) is shifting upwards in 1999 while the frequency of price decreases $\left(f p c_{t}^{-}\right)$stays relatively constant.

The VAT changes are another candidate for a factor affecting price adjustment frequencies. The VAT replaced the turnover tax on goods (6.2\%) in Q1 1995. Initially, the tax rate was set at 6.5\% for most goods and services. In Q1 1999 and Q1 2001, it was raised to $7.5 \%$ and $7.6 \%$ respectively. ${ }^{14}$ The $f p c_{t}$ series plotted in Figure 2 shows considerable spikes at these three dates. As one would expect, the tax changes affected the frequency of price increases $\left(f p c_{t}^{+}\right)$, while the frequency of price decreases $\left(f p c_{t}^{-}\right)$remained largely unchanged. In all three cases, the size of the price increase was slightly lower than in the two adjoining quarters.

In order to test more formally, whether inflation and VAT changes influences price-setting behaviour, we can estimate the model

$$
y_{j t}=w_{t} \alpha_{j}+\pi_{t} \beta+v a t_{t} \gamma+u_{j t}, \quad t=1,2, \ldots, T, j=1,2, \ldots, J,
$$

where $y_{j t} \in\left\{f p c_{j t}^{(+,-)}, S i z e_{j t}^{(+,-)}\right\}$denotes the frequency or size of price adjustments in index item $j$ at time $t, \alpha_{j}$ is a $5 \times 1$ vector of item-specific slopes, $w_{t}$ is a $1 \times 5$ vector of deterministic functions of time (constant, time trend and three seasonal dummies), $\pi_{t}$ denotes the quarter-on-quarter CPI inflation rate, and $u_{j t}$ is a group-specific disturbance term. ${ }^{15}$ In addition, we control for VAT changes

13 The inflation rates were calculated from the seasonally adjusted (trend component) CPI, since there is substantial short-term volatility after 2000 when the FSO began to collect end-ofseason sales prices.

14 Note that some products are benefiting from reduced VAT rates. For food, the rate started at $2 \%$ and was later raised to $2.3 \%$ and $2.4 \%$ respectively. For hotels and restaurants the corresponding rates were $3.0 \%, 3.5 \%$ and $3.6 \%$ respectively. In these sectors, the characteristic spikes of the $f p c_{t}$ due to VAT rate changes are much less pronounced. 
by a set of dummy variables $\left(v a t_{t}\right)$. The coefficients $\beta$ and $\gamma$ can be estimated by the fixed-effects estimator such that unobserved group specific characteristics $\left(w_{t} \alpha_{j}\right)$ drop out (see Wooldridge, 2005).

Table 6: Effect of Changes in Inflation and VAT Rates

\begin{tabular}{|c|c|c|c|c|c|c|}
\hline & $f p c_{t}$ & Size $_{t}$ & $f p c_{t}^{+}$ & $f p c_{t}^{-}$ & Size $_{t}^{+}$ & Size $_{t}^{-}$ \\
\hline$\pi_{t}$ & $\begin{array}{l}2.61^{*} \\
{[0.53]}\end{array}$ & $\begin{array}{c}0.47 \\
{[0.31]}\end{array}$ & $\begin{array}{c}1.74^{*} \\
{[0.42]}\end{array}$ & $\begin{array}{c}0.45 \\
{[0.68]}\end{array}$ & $\begin{array}{r}0.26 \\
{[0.45]}\end{array}$ & $\begin{array}{c}0.12 \\
{[0.32]}\end{array}$ \\
\hline$v a t_{95}$ & $\begin{array}{c}13.44^{*} \\
{[1.46]}\end{array}$ & $\begin{array}{c}-2.28^{*} \\
{[0.29]}\end{array}$ & $\begin{array}{c}13.64^{*} \\
{[1.52]}\end{array}$ & $\begin{array}{c}0.00 \\
{[0.66]}\end{array}$ & $\begin{array}{c}-2.15^{*} \\
{[0.40]}\end{array}$ & $\begin{array}{c}-1.08^{*} \\
{[0.32]}\end{array}$ \\
\hline$v_{a t} t_{99}$ & $\begin{array}{l}3.84^{*} \\
{[0.90]}\end{array}$ & $\begin{array}{c}-2.39^{*} \\
{[0.22]}\end{array}$ & $\begin{array}{l}4.24^{*} \\
{[0.90]}\end{array}$ & $\begin{array}{r}-0.71 \\
{[0.54]}\end{array}$ & $\begin{array}{c}-2.48^{*} \\
{[0.27]}\end{array}$ & $\begin{array}{r}-0.66 \\
{[0.36]}\end{array}$ \\
\hline$v_{a t} t_{01}$ & $\begin{array}{l}11.04^{*} \\
{[0.92]}\end{array}$ & $\begin{array}{c}-0.83^{*} \\
{[0.33]}\end{array}$ & $\begin{array}{c}9.91^{*} \\
{[0.93]}\end{array}$ & $\begin{array}{c}1.39^{*} \\
{[0.63]}\end{array}$ & $\begin{array}{c}-0.98^{*} \\
{[0.47]}\end{array}$ & $\begin{array}{c}0.42 \\
{[0.37]}\end{array}$ \\
\hline$v a t_{95}^{p r e}$ & $\begin{array}{r}0.03 \\
{[0.55]}\end{array}$ & $\begin{array}{r}-0.22 \\
{[0.20]}\end{array}$ & $\begin{array}{c}0.07 \\
{[0.52]}\end{array}$ & $\begin{array}{c}0.05 \\
{[0.58]}\end{array}$ & $\begin{array}{r}-0.28 \\
{[0.27]}\end{array}$ & $\begin{array}{r}-0.18 \\
{[0.23]}\end{array}$ \\
\hline$v_{a t}^{p r e}$ & $\begin{array}{c}-1.75^{*} \\
{[0.37]}\end{array}$ & $\begin{array}{r}-0.41 \\
{[0.23]}\end{array}$ & $\begin{array}{c}-1.22^{*} \\
{[0.49]}\end{array}$ & $\begin{array}{r}-0.65 \\
{[0.42]}\end{array}$ & $\begin{array}{c}-0.54^{*} \\
{[0.27]}\end{array}$ & $\begin{array}{r}-0.42 \\
{[0.24]}\end{array}$ \\
\hline$v a t_{01}^{p r e}$ & $\begin{array}{c}0.07 \\
{[0.46]}\end{array}$ & $\begin{array}{r}-0.05 \\
{[0.25]}\end{array}$ & $\begin{array}{r}0.36 \\
{[0.37]}\end{array}$ & $\begin{array}{r}-0.07 \\
{[0.45]}\end{array}$ & $\begin{array}{r}-0.14 \\
{[0.33]}\end{array}$ & $\begin{array}{c}0.79^{*} \\
{[0.27]}\end{array}$ \\
\hline$v_{a t}{ }_{95}^{a n n}$ & $\begin{array}{r}-0.30 \\
{[0.58]}\end{array}$ & $\begin{array}{c}0.13 \\
{[0.24]}\end{array}$ & $\begin{array}{r}0.86 \\
{[0.45]}\end{array}$ & $\begin{array}{r}-0.82 \\
{[0.48]}\end{array}$ & $\begin{array}{c}0.11 \\
{[0.27]}\end{array}$ & $\begin{array}{r}0.40 \\
{[0.30]}\end{array}$ \\
\hline$v_{a t}^{a n n}$ & $\begin{array}{c}-1.32 * \\
{[0.37]}\end{array}$ & $\begin{array}{c}0.32 \\
{[0.22]}\end{array}$ & $\begin{array}{r}-0.47 \\
{[0.35]}\end{array}$ & $\begin{array}{r}-0.66 \\
{[0.38]}\end{array}$ & $\begin{array}{l}0.61^{*} \\
{[0.29]}\end{array}$ & $\begin{array}{c}0.14 \\
{[0.22]}\end{array}$ \\
\hline vat $t_{01}^{a n n}$ & $\begin{array}{r}-0.79 \\
{[0.58]}\end{array}$ & $\begin{array}{c}-1.13^{*} \\
{[0.30]}\end{array}$ & $\begin{array}{c}0.22 \\
{[0.60]}\end{array}$ & $\begin{array}{r}-0.61 \\
{[0.49]}\end{array}$ & $\begin{array}{c}-1.03^{*} \\
{[0.32]}\end{array}$ & $\begin{array}{c}-0.68^{*} \\
{[0.28]}\end{array}$ \\
\hline$J$ & 138 & 138 & 138 & 138 & 138 & 138 \\
\hline$T$ & 50 & 50 & 50 & 50 & 50 & 50 \\
\hline
\end{tabular}

Note: The table gives the effect of changes in inflation and VAT rates on the frequency and size of price adjustments. Dummies for VAT changes equal 1 in the quarter the change took effect $\left(v a t_{y y}\right)$, in the two quarters before the change $\left(v a t^{\text {pre }}\right)$, and in the quarter the change was adopted by parliament and thus announced $\left(v a t^{a n n}\right)$. The fixed effects estimation takes place at the level of the index items. Heteroskedasticity and serial correlation consistent standard errors are given in parentheses (see Arellano, 1987). *: Significant at the 5\% level; $f p c_{t}$ : Frequency of price changes (\%); Size $_{t}$ : Size of price changes (\%); $\pi_{t}$ : q/q inflation (\%); J: Number of index items; T: Number of time observations.

15 Results for the United States in a similar set-up are provided by NaKamura and Steinsson (2008). 
Table 6 displays the estimated coefficients on inflation and the VAT dummies along with the heteroskedasticity and serial correlation consistent standard errors suggested by ARELLANo (1987) in parentheses. The coefficients give the average effect of a change in the covariates on the frequency or size of price adjustment, holding fixed the group-specific differences. The estimation is based on data from 138 index items $(J)$ over 50 quarters $(T)$.

A one-percent increase in quarter-on-quarter inflation leads to a 2.61 percent increase in the frequency of price changes. Although inflation has a positive effect on the size of price adjustment, the coefficient is not significant. A breakdown into positive and negative price changes shows that inflation raises the frequency of price increases $\left(f p c_{t}^{+}\right)$, but the frequency of price decreases $\left(f p c_{t}^{-}\right)$is not significantly affected.

VAT changes have a significant effect on the frequency of price changes $\left(v a t_{y y}\right)$. From the separate regressions for price increases and decreases, it turns out that firms actually adjust the share of increases whereas the share of decreases is not significantly affected or the effect is of the wrong sign. The size of price changes, on the other hand, is significantly reduced in response to the VAT changes, since the average VAT change was lower than the average size of a regular price change. Interestingly, firms seem to react much more strongly by adjusting the share and size of price increases than the share and size of price decreases.

A typical TDP predicts that changes in the VAT rate lead to a change in the size of price adjustments, but the timing remains fixed. According to SDP, on the other hand, we would expect that a firm changes its price, as soon as the tax change is announced. Firms should be more likely to adjust prices and there should be a reduction in the frequency of price cuts as there is a predictable cost increase approaching. In order to test for such an effect of the VAT change, the regressions include dummy variables which equal 1 in the two quarters before the change $\left(v a t_{y y}^{p r e}\right)$ and in the quarter the change was adopted by parliament and thus announced $\left(v a t_{y y}^{a n n}\right)$. The coefficients generally are small, not significant, or even of the wrong sign. The only exceptions, which are in line with an announcement effect, are two significant coefficients measuring the effect on the size of price increases and decreases in 1999 and 2001. Overall, the regression results suggest, however, that firms do not systematically adjust prices before the changes in VAT rates take effect.

Our findings suggest that there are forces at work which prevent firms from raising prices prior to an increase in the VAT, even if this increase is broadly anticipated. Two reasons may apply. First, firms are concerned with the effects of their pricing decisions on customer relationships. From this perspective, price 
increases are easier to communicate if the tax change has taken effect than if the change is simply known to take place at the same time in the future. Second, a change in the VAT rate may serve as a focal point between competitors in order to coordinate price increases which would otherwise lead to a loss in market share if taken individually. Survey evidence lends support to both explanations. When asked why they do not rise prices in the face of anticipated cost increases, a large share of firms in an US survey responded that this could antagonise their customers and/or that they worry that competing firms will not raise their prices also (see BLINDER et al., 1998, p. 204).

\section{Conclusions}

This paper provides evidence about price-setting behaviour in Switzerland. Based on a large data set with micro data from the CPI for the period from 1993 to 2005, several conclusions emerge from the analysis:

1. The median price duration amounts to 4.6 quarters between 2000 and 2005 (4.8 quarters during 1993-2000). This duration is somewhat longer than that obtained by studies on other countries.

2. The median price duration is heterogeneous across sectors and in outlets of different size. Factors like the labour share in production, the storability of the good, and the importance attributed to customer relations for price setting may play an important role in explaining the differences among price durations.

3. Price changes are sizable. Between 2000 and 2005, the median absolute size of all price changes was $9.4 \%$ (9.0\% in 1993-2000).

4. There is little evidence of downward rigidity of prices. Between 2000 and $2005,41.3 \%$ of all price changes have been price decreases (43.8\% in 19932000). Thus, even during periods with positive CPI inflation, a considerable share of all price changes are decreases. Moreover, the distributions of price changes are generally symmetric. An exception is the service sector, however, suggesting that downward rigidities in consumer prices occur mostly due to downward rigid wages.

5. Prices are not adjusted in anticipation of VAT rate changes. They are adjusted in the quarter in which the VAT rate change takes effect. In addition, firms do not reduce the share of price decreases due to an anticipated cost shock.

6. Macroeconomic factors, such as changes in inflation, appear to affect the frequency of price changes. This is consistent with predictions from SDP models. Because the rate of inflation remained fairly stable during the period under 
review, the evidence for the effect of inflation on price-setting behaviour is limited, however.

Compared to other countries, Switzerland exhibits higher median durations of prices. This could be due lower inflation rates or a less competitive domestic sector than in the euro area or the United States for example.

The duration statistics (or the corresponding frequencies of price changes) presented here can be used in the calibration of micro-founded macroeconomic models. They represent the first estimates of price duration in the Swiss economy based on CPI micro data. 


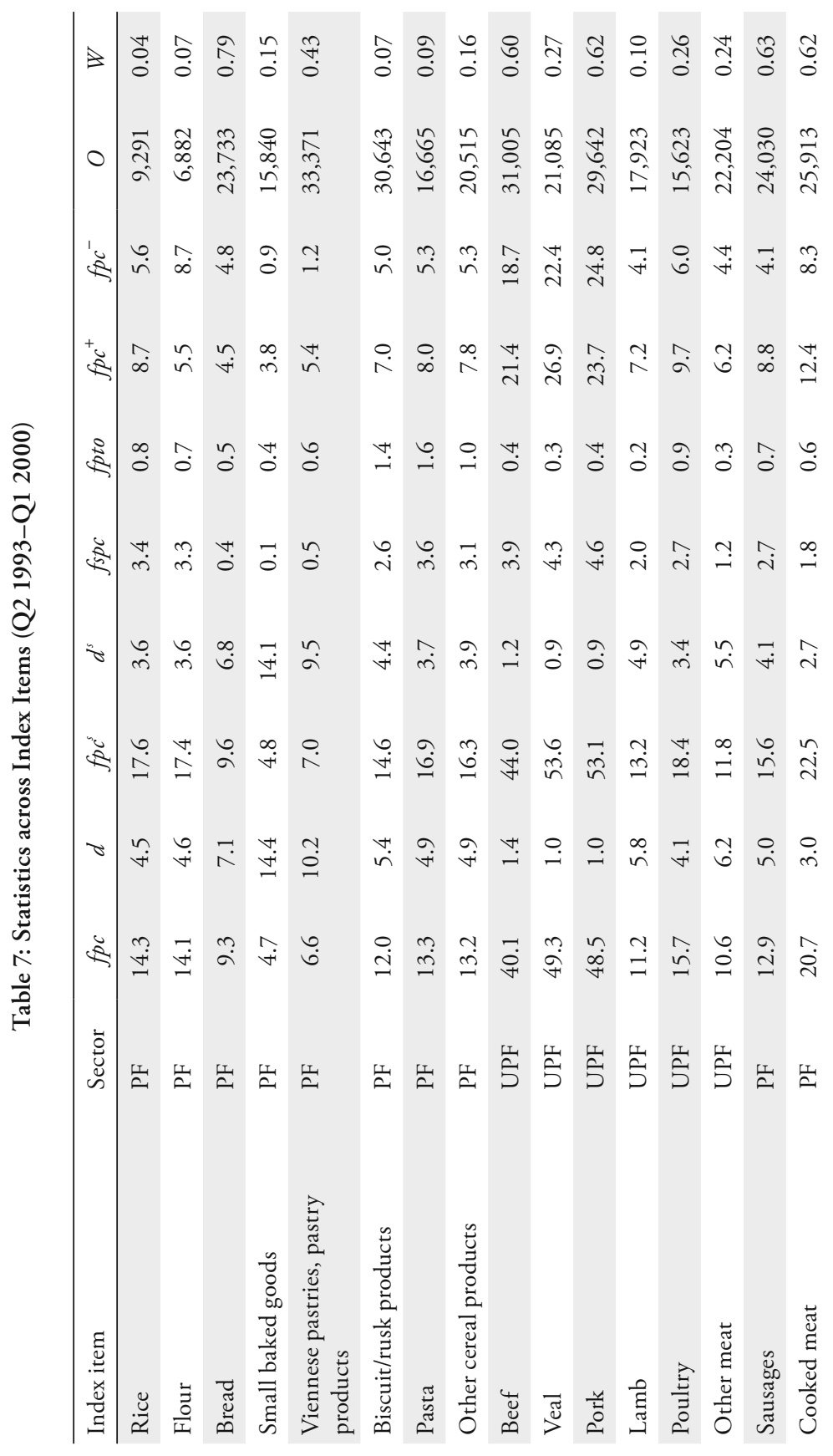




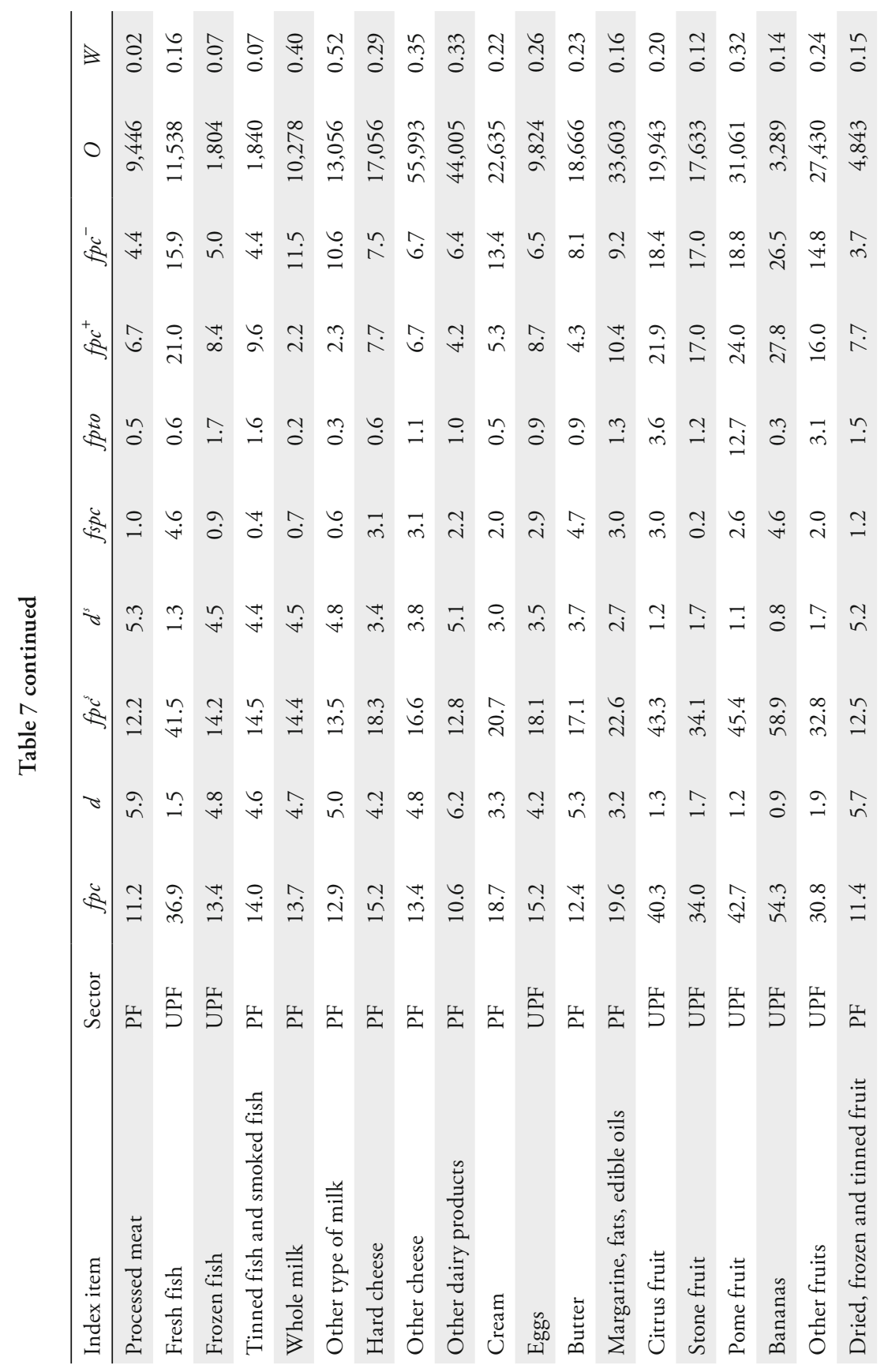




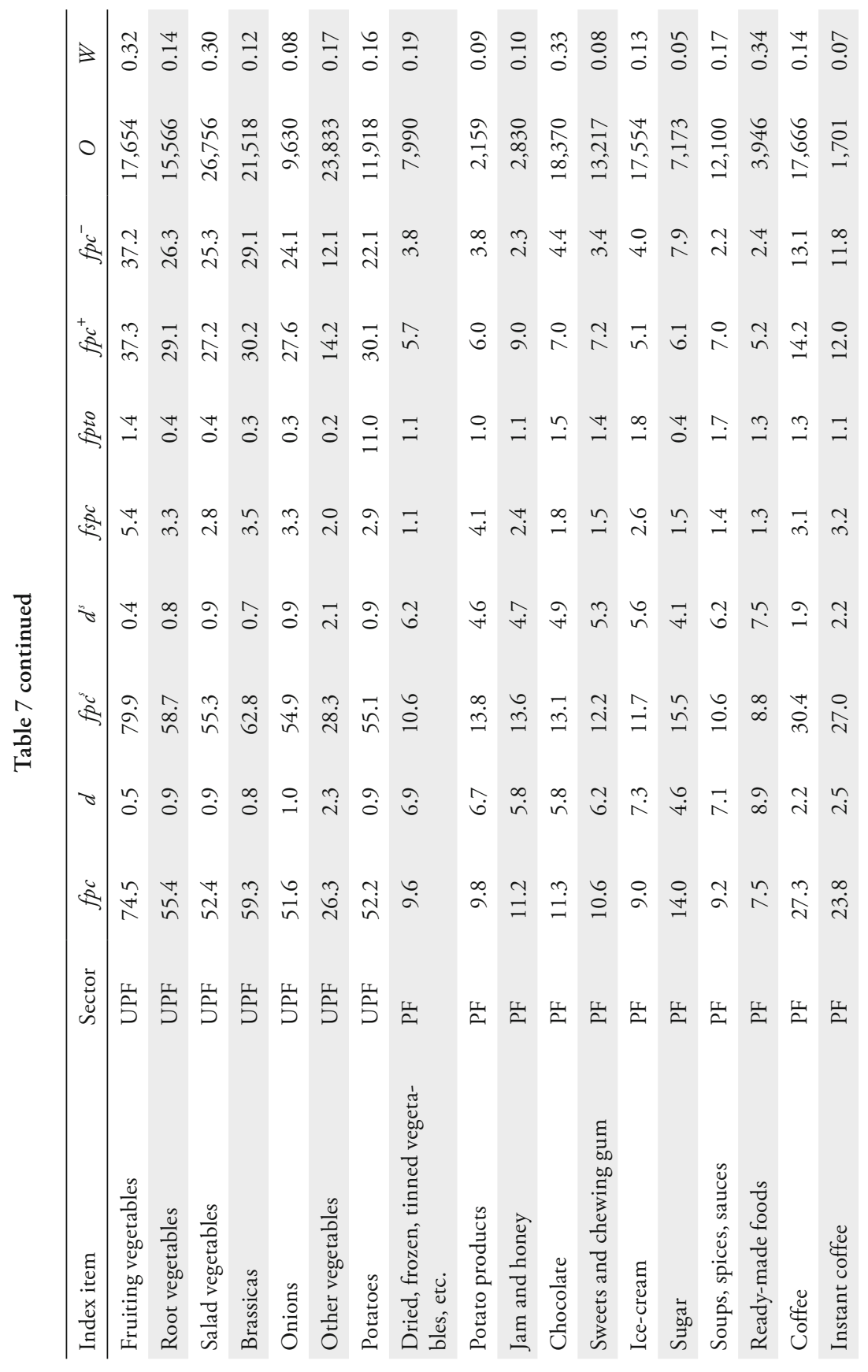




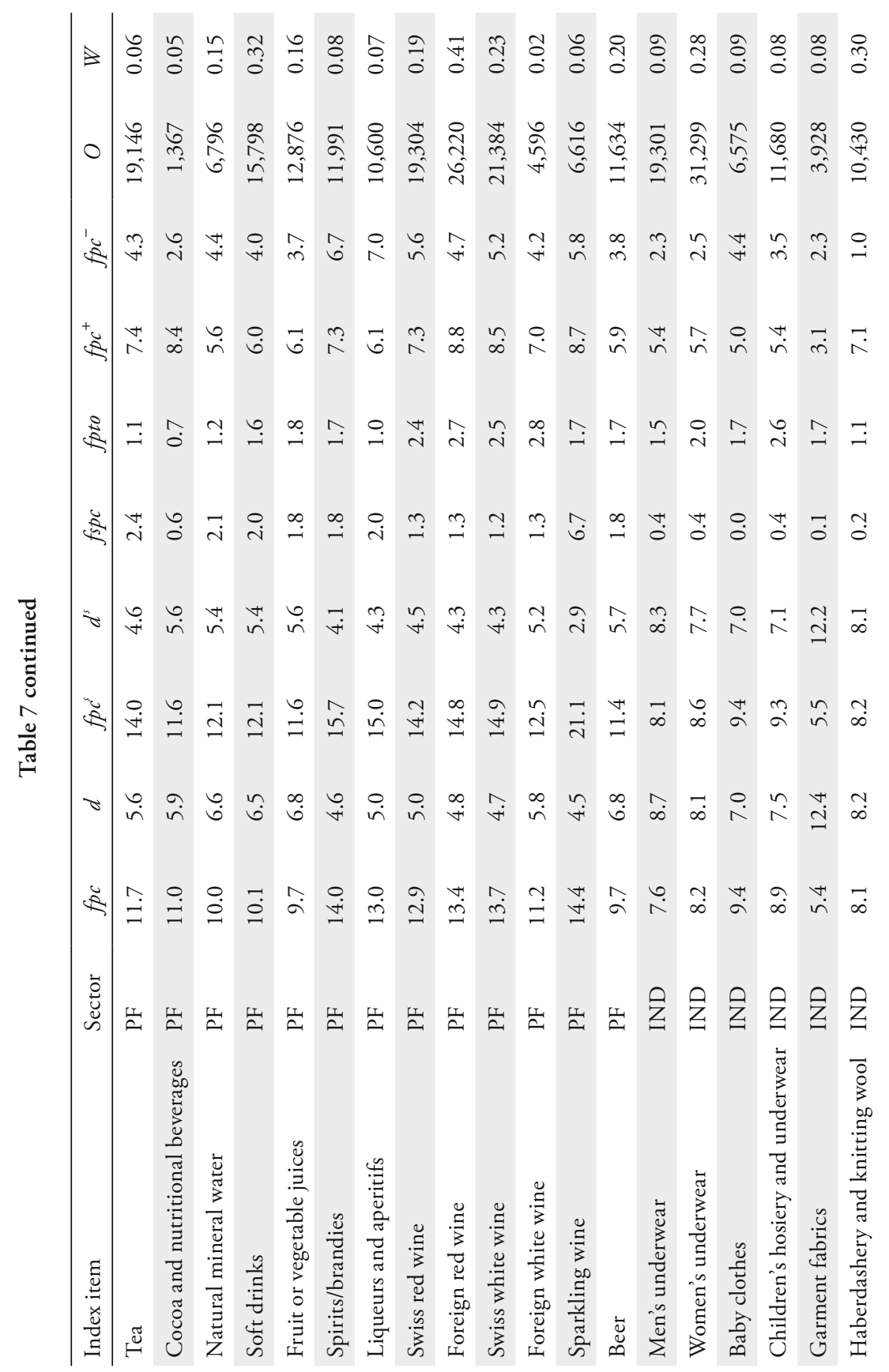




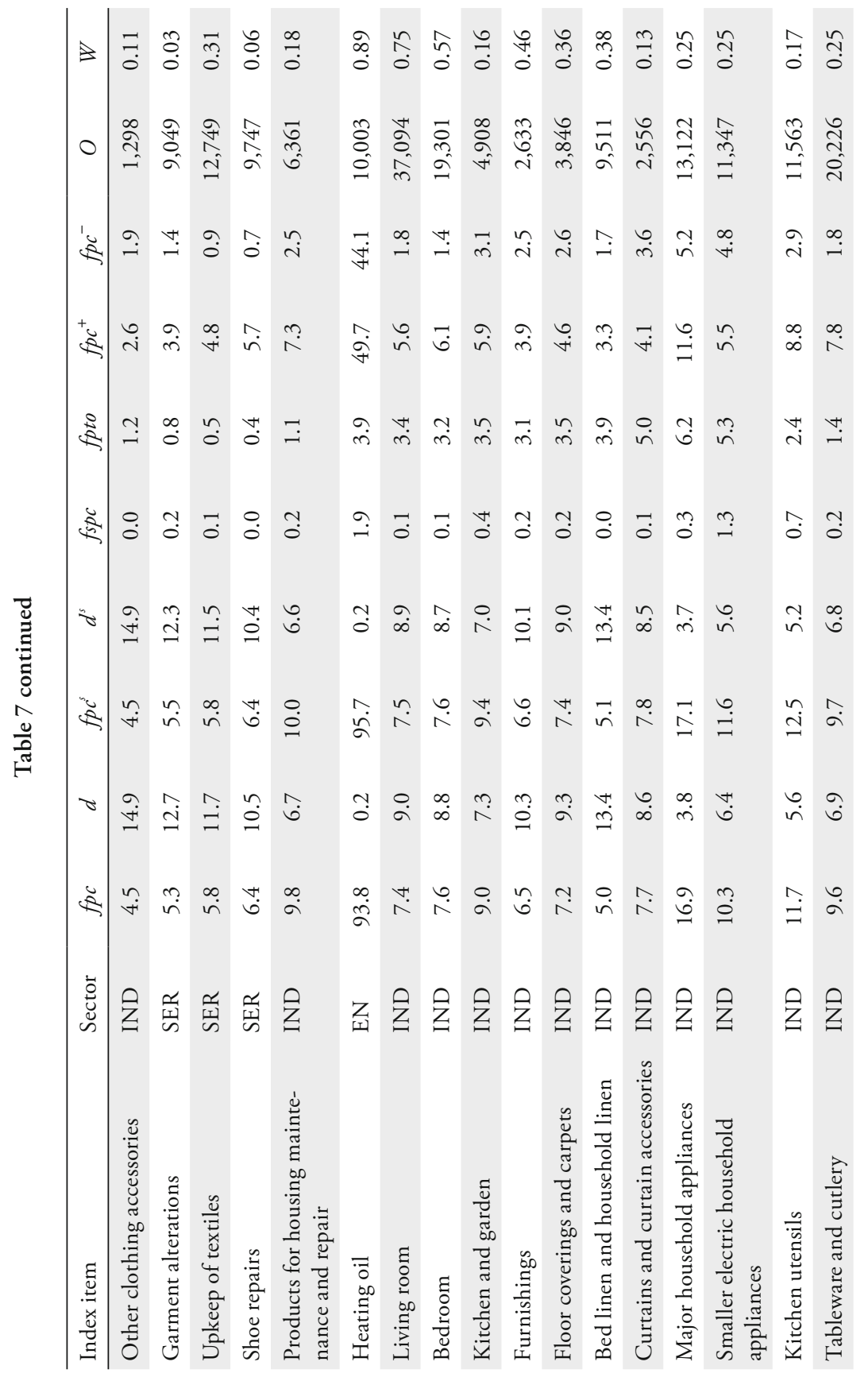




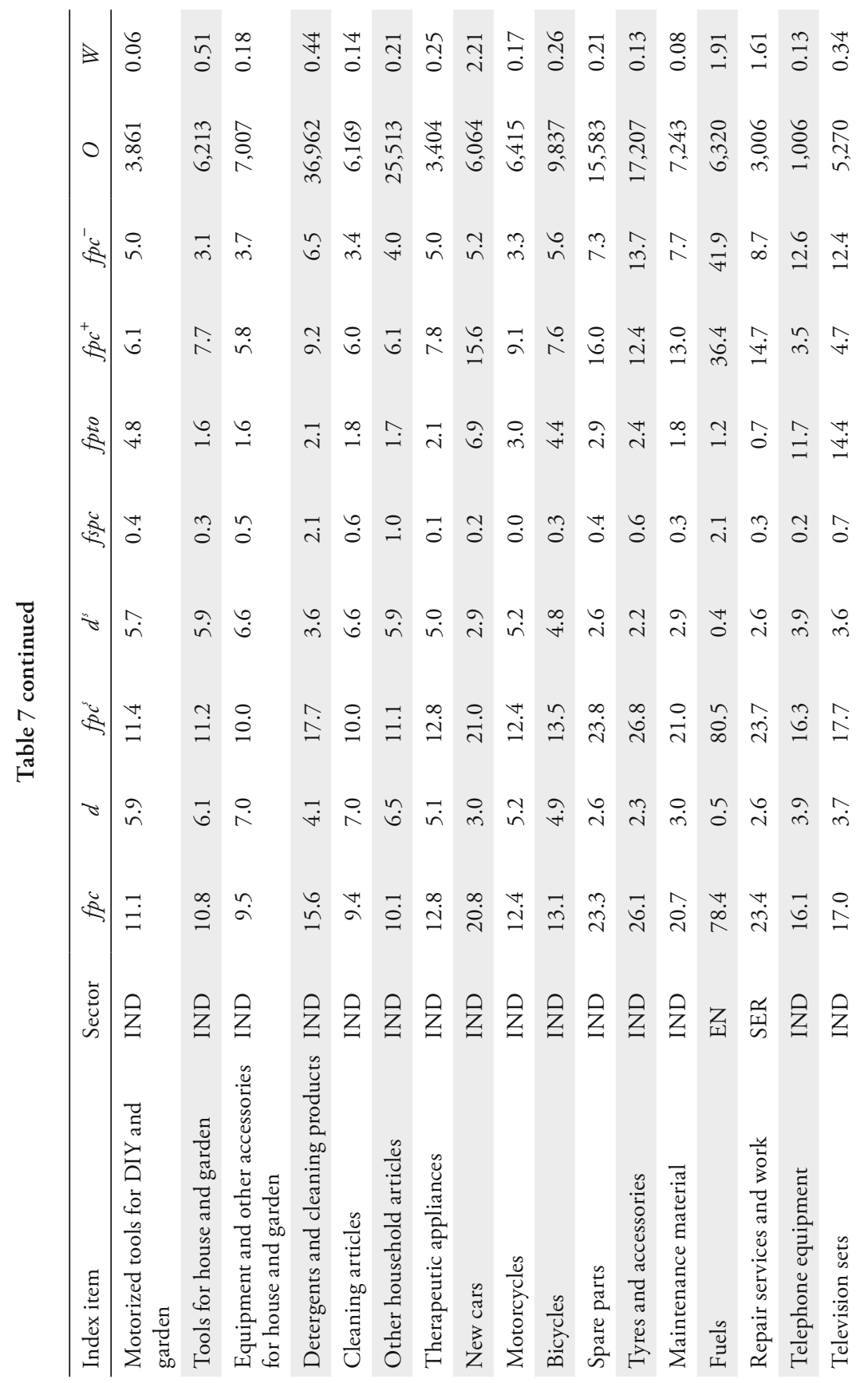




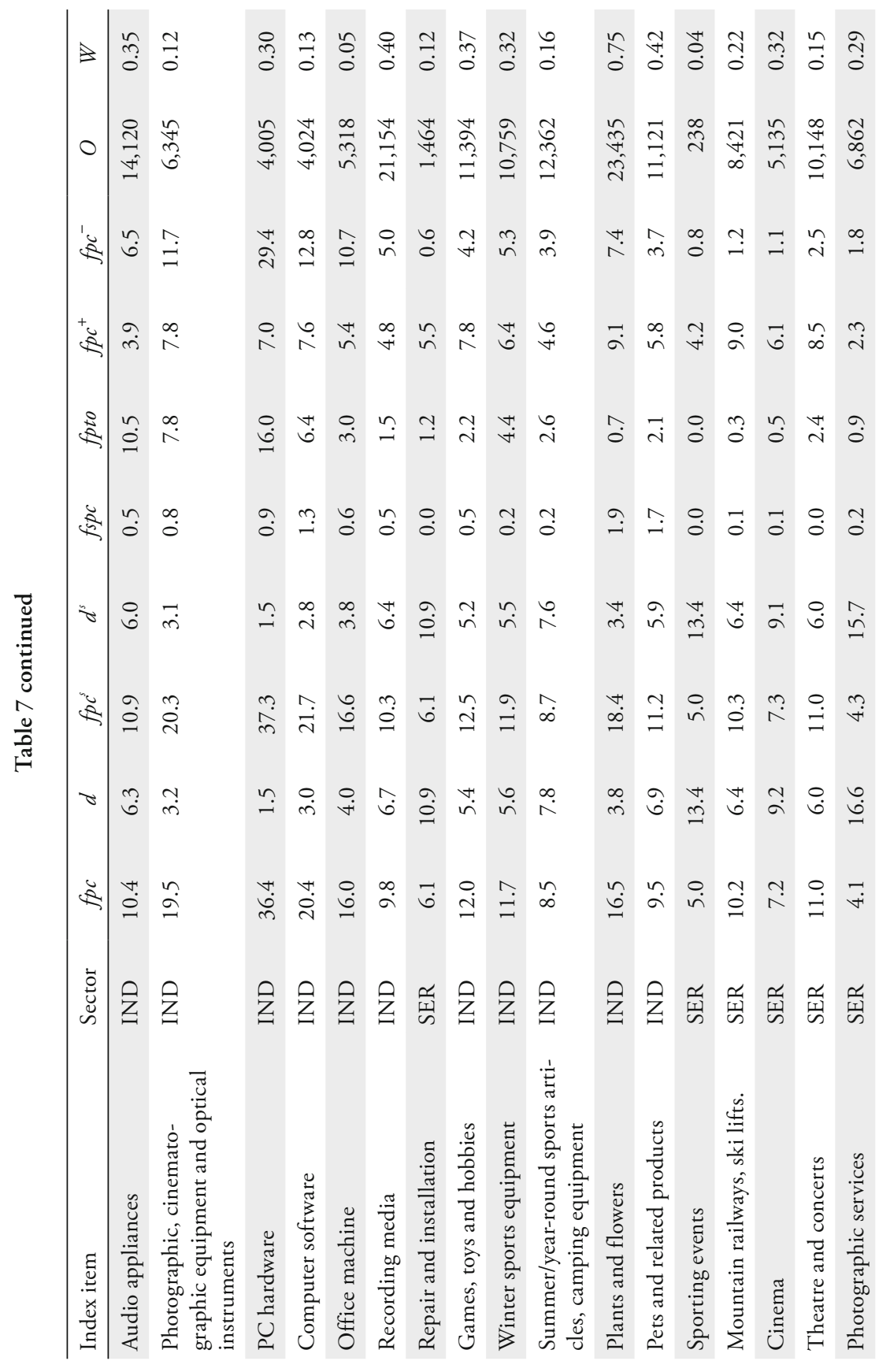




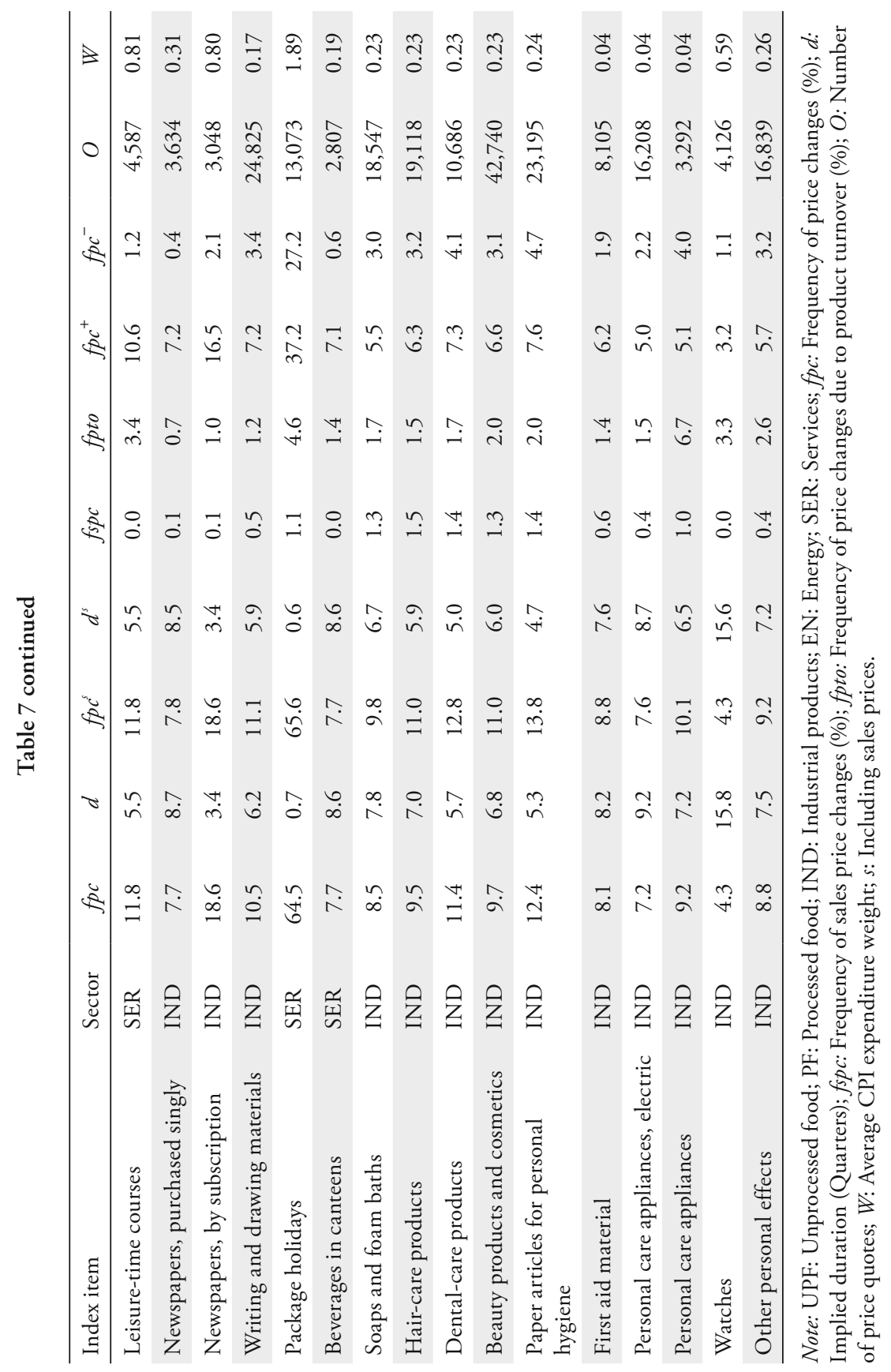


Table 8: Statistics across Index Items (Q2 1993-Q1 2000)

\begin{tabular}{|c|c|c|c|c|c|}
\hline Index item & Sector & Size & $\mathrm{Size}^{+}$ & $S_{i z e^{-}}$ & Sizes \\
\hline Rice & $\mathrm{PF}$ & 10.3 & 10.4 & 10.2 & 12.2 \\
\hline Flour & $\mathrm{PF}$ & 8.8 & 10.0 & 8.1 & 11.1 \\
\hline Bread & $\mathrm{PF}$ & 5.8 & 5.6 & 6.0 & 6.2 \\
\hline Small baked goods & $\mathrm{PF}$ & 11.3 & 10.9 & 12.9 & 11.2 \\
\hline Viennese pastries, pastry products & $\mathrm{PF}$ & 8.9 & 8.2 & 12.2 & 9.7 \\
\hline Biscuit/rusk products & $\mathrm{PF}$ & 9.8 & 8.9 & 11.0 & 11.1 \\
\hline Pasta & $\mathrm{PF}$ & 13.0 & 12.6 & 13.6 & 15.3 \\
\hline Other cereal products & $\mathrm{PF}$ & 10.5 & 9.9 & 11.4 & 13.0 \\
\hline Beef & UPF & 10.5 & 11.1 & 9.8 & 10.8 \\
\hline Veal & UPF & 9.3 & 9.6 & 8.8 & 9.3 \\
\hline Pork & UPF & 12.0 & 13.9 & 10.3 & 12.0 \\
\hline Lamb & UPF & 12.3 & 12.6 & 11.9 & 13.6 \\
\hline Poultry & UPF & 11.7 & 11.4 & 12.1 & 13.1 \\
\hline Other meat & UPF & 15.9 & 15.4 & 16.5 & 16.3 \\
\hline Sausages & $\mathrm{PF}$ & 11.2 & 10.6 & 12.5 & 14.2 \\
\hline Cooked meat & $\mathrm{PF}$ & 10.3 & 10.9 & 9.4 & 10.8 \\
\hline Processed meat & PF & 10.5 & 10.9 & 10.0 & 10.9 \\
\hline Fresh fish & UPF & 14.1 & 15.0 & 13.0 & 14.5 \\
\hline Frozen fish & UPF & 7.4 & 7.3 & 7.6 & 8.4 \\
\hline Tinned fish and smoked fish & $\mathrm{PF}$ & 8.3 & 7.6 & 10.0 & 8.6 \\
\hline Whole milk & $\mathrm{PF}$ & 5.9 & 6.1 & 5.9 & 6.3 \\
\hline Other type of milk & $\mathrm{PF}$ & 6.0 & 5.4 & 6.1 & 6.1 \\
\hline Hard cheese & $\mathrm{PF}$ & 8.4 & 9.0 & 7.8 & 10.3 \\
\hline Other cheese & $\mathrm{PF}$ & 8.6 & 9.2 & 8.1 & 10.3 \\
\hline Other dairy products & PF & 9.0 & 9.5 & 8.7 & 11.3 \\
\hline Cream & $\mathrm{PF}$ & 7.6 & 7.0 & 7.8 & 8.6 \\
\hline Eggs & UPF & 8.3 & 8.3 & 8.3 & 9.4 \\
\hline Butter & $\mathrm{PF}$ & 6.5 & 7.7 & 6.0 & 9.4 \\
\hline Margarine, fats, edible oils & $\mathrm{PF}$ & 8.1 & 7.3 & 9.1 & 9.4 \\
\hline Citrus fruit & UPF & 23.1 & 25.4 & 20.3 & 22.6 \\
\hline
\end{tabular}


Table 8 continued

\begin{tabular}{|c|c|c|c|c|c|}
\hline Index item & Sector & Size & $\mathrm{Size}^{+}$ & Size & $S i z e^{s}$ \\
\hline Stone fruit & UPF & 47.9 & 63.5 & 32.2 & 48.0 \\
\hline Pome fruit & UPF & 19.0 & 20.4 & 17.3 & 19.0 \\
\hline Bananas & UPF & 15.9 & 18.5 & 13.1 & 16.2 \\
\hline Other fruits & UPF & 30.8 & 37.3 & 23.9 & 30.6 \\
\hline Dried, frozen and tinned fruit & $\mathrm{PF}$ & 10.3 & 10.0 & 10.9 & 11.4 \\
\hline Fruiting vegetables & UPF & 27.9 & 33.7 & 22.0 & 27.6 \\
\hline Root vegetables & UPF & 26.1 & 29.8 & 22.0 & 25.6 \\
\hline Salad vegetables & UPF & 31.0 & 37.6 & 23.9 & 30.7 \\
\hline Brassicas & UPF & 26.5 & 31.4 & 21.5 & 26.3 \\
\hline Onions & UPF & 30.5 & 34.8 & 25.6 & 29.7 \\
\hline Other vegetables & UPF & 23.2 & 26.4 & 19.3 & 23.0 \\
\hline Potatoes & UPF & 22.4 & 23.7 & 20.7 & 21.5 \\
\hline $\begin{array}{l}\text { Dried, frozen, tinned vegetables, } \\
\text { etc. }\end{array}$ & PF & 8.2 & 7.5 & 9.5 & 9.5 \\
\hline Potato products & PF & 11.6 & 11.0 & 12.5 & 15.4 \\
\hline Jam and honey & PF & 7.1 & 6.7 & 8.6 & 9.5 \\
\hline Chocolate & $\mathrm{PF}$ & 9.5 & 9.0 & 10.4 & 10.7 \\
\hline Sweets and chewing gum & $\mathrm{PF}$ & 10.5 & 9.4 & 12.8 & 11.7 \\
\hline Ice-cream & $\mathrm{PF}$ & 11.4 & 11.6 & 11.1 & 14.1 \\
\hline Sugar & PF & 6.9 & 6.4 & 7.3 & 7.6 \\
\hline Soups, spices, sauces & $\mathrm{PF}$ & 7.3 & 6.6 & 9.5 & 9.2 \\
\hline Ready-made foods & $\mathrm{PF}$ & 7.3 & 6.6 & 8.7 & 9.7 \\
\hline Coffee & $\mathrm{PF}$ & 12.2 & 14.5 & 9.7 & 12.6 \\
\hline Instant coffee & $\mathrm{PF}$ & 8.3 & 9.0 & 7.5 & 9.1 \\
\hline Tea & $\mathrm{PF}$ & 9.1 & 8.2 & 10.6 & 10.5 \\
\hline Cocoa and nutritional beverages & $\mathrm{PF}$ & 6.4 & 5.7 & 8.8 & 6.7 \\
\hline Natural mineral water & PF & 11.8 & 11.6 & 11.9 & 15.1 \\
\hline Soft drinks & $\mathrm{PF}$ & 10.7 & 10.4 & 11.2 & 12.8 \\
\hline Fruit or vegetable juices & $\mathrm{PF}$ & 9.5 & 8.8 & 10.5 & 12.0 \\
\hline Spirits/brandies & $\mathrm{PF}$ & 7.9 & 5.3 & 10.8 & 7.8 \\
\hline Liqueurs and aperitifs & $\mathrm{PF}$ & 8.4 & 5.7 & 10.7 & 8.6 \\
\hline
\end{tabular}


Table 8 continued

\begin{tabular}{|c|c|c|c|c|c|}
\hline Index item & Sector & Size & $S_{i z e}^{+}$ & Size $e^{-}$ & Size \\
\hline Swiss red wine & $\mathrm{PF}$ & 7.2 & 6.6 & 8.0 & 7.8 \\
\hline Foreign red wine & $\mathrm{PF}$ & 9.7 & 9.5 & 10.0 & 10.2 \\
\hline Swiss white wine & $\mathrm{PF}$ & 8.0 & 7.6 & 8.6 & 8.6 \\
\hline Foreign white wine & $\mathrm{PF}$ & 9.4 & 8.4 & 11.0 & 10.6 \\
\hline Sparkling wine & $\mathrm{PF}$ & 8.1 & 7.8 & 8.5 & 10.1 \\
\hline Beer & $\mathrm{PF}$ & 8.9 & 7.9 & 10.5 & 10.1 \\
\hline Men's underwear & IND & 10.5 & 10.1 & 11.4 & 10.8 \\
\hline Women's underwear & IND & 11.0 & 10.4 & 12.5 & 11.0 \\
\hline Baby clothes & IND & 13.1 & 13.8 & 12.4 & 13.2 \\
\hline Children's hosiery and underwear & IND & 11.3 & 11.6 & 10.9 & 11.1 \\
\hline Garment fabrics & IND & 10.3 & 8.8 & 12.4 & 10.9 \\
\hline Haberdashery and knitting wool & IND & 7.6 & 7.4 & 9.7 & 7.6 \\
\hline Other clothing accessories & IND & 10.8 & 10.2 & 11.8 & 10.8 \\
\hline Garment alterations & SER & 16.8 & 17.8 & 13.7 & 16.9 \\
\hline Upkeep of textiles & SER & 8.2 & 7.6 & 12.0 & 8.5 \\
\hline Shoe repairs & SER & 6.7 & 6.7 & 7.4 & 6.7 \\
\hline $\begin{array}{l}\text { Products for housing maintenance } \\
\text { and repair }\end{array}$ & IND & 7.9 & 7.4 & 9.4 & 7.9 \\
\hline Heating oil & $\mathrm{EN}$ & 8.3 & 10.1 & 6.2 & 8.2 \\
\hline Living room & IND & 5.9 & 5.3 & 7.6 & 6.2 \\
\hline Bedroom & IND & 5.9 & 5.2 & 9.0 & 5.9 \\
\hline Kitchen and garden & IND & 9.3 & 7.8 & 12.4 & 9.6 \\
\hline Furnishings & IND & 9.3 & 7.0 & 13.0 & 9.8 \\
\hline Floor coverings and carpets & IND & 7.7 & 5.9 & 10.9 & 8.0 \\
\hline Bed linen and household linen & IND & 11.5 & 8.7 & 17.2 & 12.1 \\
\hline Curtains and curtain accessories & IND & 10.9 & 9.2 & 12.9 & 11.7 \\
\hline Major household appliances & IND & 4.8 & 3.7 & 7.1 & 4.6 \\
\hline $\begin{array}{l}\text { Smaller electric household } \\
\text { appliances }\end{array}$ & IND & 11.6 & 10.3 & 13.1 & 13.2 \\
\hline Kitchen utensils & IND & 8.7 & 8.1 & 10.8 & 9.4 \\
\hline Tableware and cutlery & IND & 8.0 & 7.6 & 10.4 & 8.0 \\
\hline
\end{tabular}


Table 8 continued

\begin{tabular}{|c|c|c|c|c|c|}
\hline Index item & Sector & Size & $\mathrm{Size}^{+}$ & Size $e^{-}$ & Sizes \\
\hline $\begin{array}{l}\text { Motorized tools for DIY and } \\
\text { garden }\end{array}$ & IND & 8.2 & 6.4 & 10.5 & 8.4 \\
\hline Tools for house and garden & IND & 8.3 & 7.9 & 9.5 & 8.4 \\
\hline $\begin{array}{l}\text { Equipment and other accessories } \\
\text { for house and garden }\end{array}$ & IND & 11.1 & 10.5 & 12.0 & 11.4 \\
\hline Detergents and cleaning products & IND & 10.4 & 10.1 & 10.8 & 11.1 \\
\hline Cleaning articles & IND & 9.9 & 9.3 & 11.2 & 10.0 \\
\hline Other household articles & IND & 10.3 & 10.0 & 10.8 & 10.8 \\
\hline Therapeutic appliances & IND & 5.9 & 5.4 & 6.8 & 5.6 \\
\hline New cars & IND & 2.4 & 2.0 & 3.4 & 2.3 \\
\hline Motorcycles & IND & 3.8 & 3.0 & 5.8 & 3.7 \\
\hline Bicycles & IND & 8.0 & 7.4 & 8.8 & 8.1 \\
\hline Spare parts & IND & 5.5 & 4.1 & 8.5 & 5.1 \\
\hline Tyres and accessories & IND & 6.4 & 5.2 & 7.6 & 6.4 \\
\hline Maintenance material & IND & 5.6 & 5.2 & 6.4 & 5.6 \\
\hline Fuels & EN & 2.7 & 3.5 & 2.0 & 2.7 \\
\hline Repair services and work & SER & 4.3 & 3.4 & 5.7 & 4.3 \\
\hline Telephone equipment & IND & 14.3 & 8.3 & 15.9 & 15.7 \\
\hline Television sets & IND & 11.4 & 8.9 & 12.3 & 12.7 \\
\hline Audio appliances & IND & 11.6 & 9.4 & 12.8 & 13.1 \\
\hline $\begin{array}{l}\text { Photographic, cinematographic } \\
\text { equipment and optical instruments }\end{array}$ & IND & 11.3 & 10.5 & 11.8 & 11.6 \\
\hline PC hardware & IND & 11.9 & 9.4 & 12.5 & 12.4 \\
\hline Computer software & IND & 13.9 & 13.2 & 14.3 & 14.4 \\
\hline Office machine & IND & 13.4 & 11.2 & 14.5 & 13.4 \\
\hline Recording media & IND & 9.9 & 9.4 & 10.4 & 10.2 \\
\hline Repair and installation & SER & 7.7 & 7.6 & 8.8 & 7.5 \\
\hline Games, toys and hobbies & IND & 10.2 & 9.4 & 11.7 & 10.4 \\
\hline Winter sports equipment & IND & 9.9 & 9.1 & 10.8 & 10.2 \\
\hline $\begin{array}{l}\text { Summer/year-round sports articles, } \\
\text { camping equipment }\end{array}$ & IND & 9.5 & 8.9 & 10.1 & 9.1 \\
\hline Plants and flowers & IND & 16.5 & 17.6 & 15.2 & 16.5 \\
\hline
\end{tabular}


Table 8 continued

\begin{tabular}{llrrrr}
\hline Index item & Sector & Size & Size $^{+}$ & Size $^{-}$ & Size $^{s^{2}}$ \\
\hline Pets and related products & IND & 9.4 & 8.9 & 10.1 & 11.3 \\
Sporting events & SER & 23.7 & 24.2 & 21.5 & 23.7 \\
Mountain railways, ski lifts. & SER & 7.3 & 6.8 & 11.4 & 7.3 \\
Cinema & SER & 10.4 & 10.4 & 10.2 & 10.4 \\
Theatre and concerts & SER & 9.1 & 9.4 & 7.2 & 9.1 \\
Photographic services & SER & 17.1 & 18.1 & 15.9 & 17.4 \\
Leisure-time courses & SER & 7.2 & 7.1 & 8.7 & 7.1 \\
Newspapers, purchased singly & IND & 10.7 & 10.0 & 23.9 & 10.7 \\
Newspapers, by subscription & IND & 4.6 & 4.4 & 6.0 & 4.6 \\
Writing and drawing materials & IND & 8.7 & 8.2 & 10.0 & 8.7 \\
Package holidays & SER & 18.4 & 19.5 & 16.9 & 18.4 \\
Beverages in canteens & SER & 12.4 & 12.5 & 11.5 & 12.4 \\
Soaps and foam baths & IND & 9.8 & 9.0 & 11.2 & 10.9 \\
Hair-care products & IND & 10.2 & 9.3 & 11.9 & 11.3 \\
Dental-care products & IND & 9.7 & 8.9 & 11.3 & 10.6 \\
Beauty products and cosmetics & IND & 9.1 & 8.5 & 10.4 & 9.9 \\
Paper articles for personal hygiene & IND & 9.8 & 9.7 & 10.0 & 10.4 \\
First aid material & IND & 6.9 & 6.6 & 8.0 & 6.8 \\
Personal care appliances, electric & IND & 9.9 & 9.6 & 10.8 & 10.2 \\
Personal care appliances & IND & 10.1 & 9.0 & 11.4 & 11.3 \\
Watches & IND & 9.0 & 7.8 & 12.3 & 9.0 \\
Other personal effects & IND & 9.6 & 8.9 & 10.9 & 9.2 \\
\hline & & & & & \\
\hline
\end{tabular}

Note: UPF: Unprocessed food; PF: Processed food; IND: Industrial products; EN: Energy; SER: Services; Size: Size of price changes (\%); s: Including sales prices. 


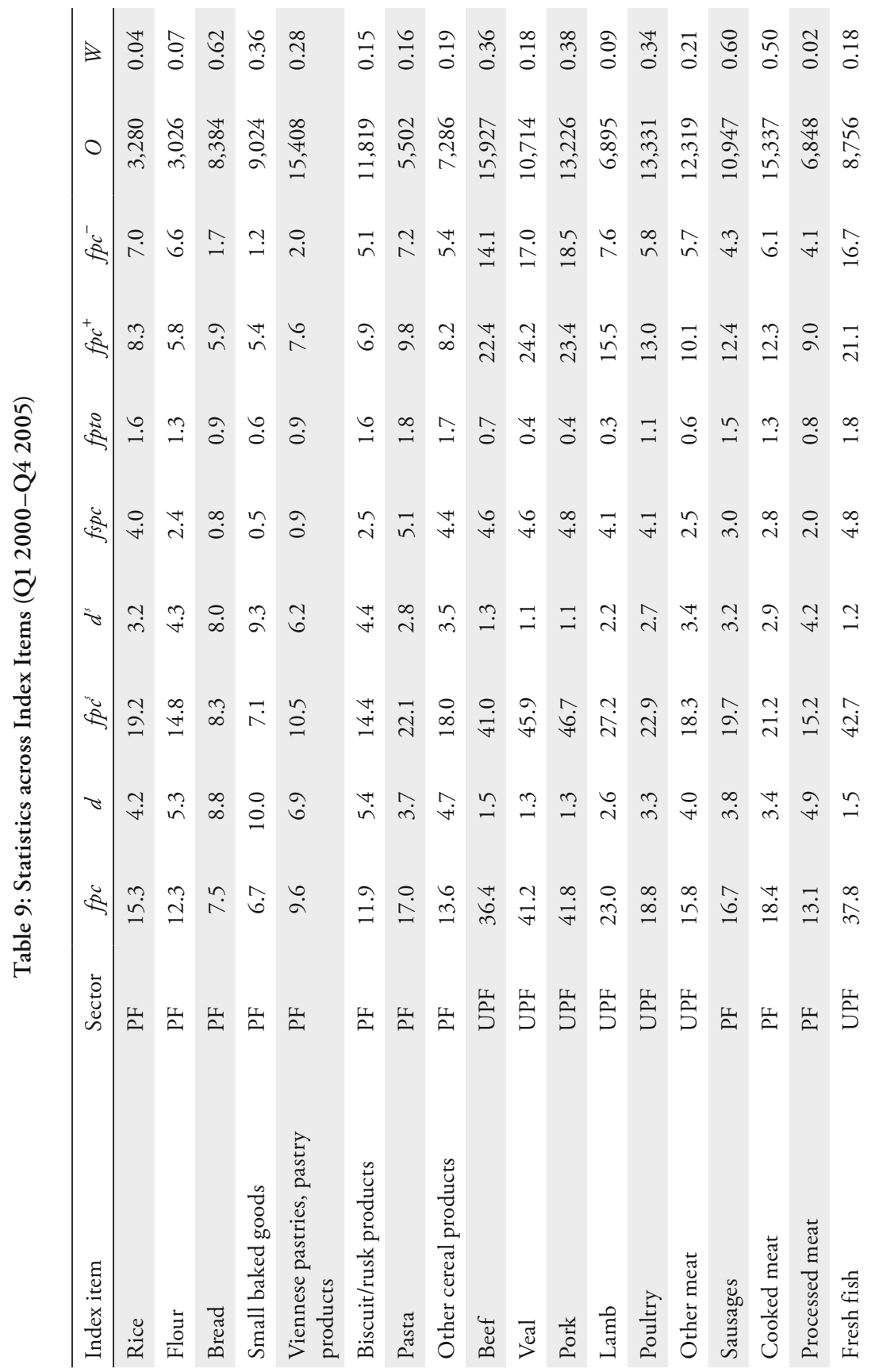




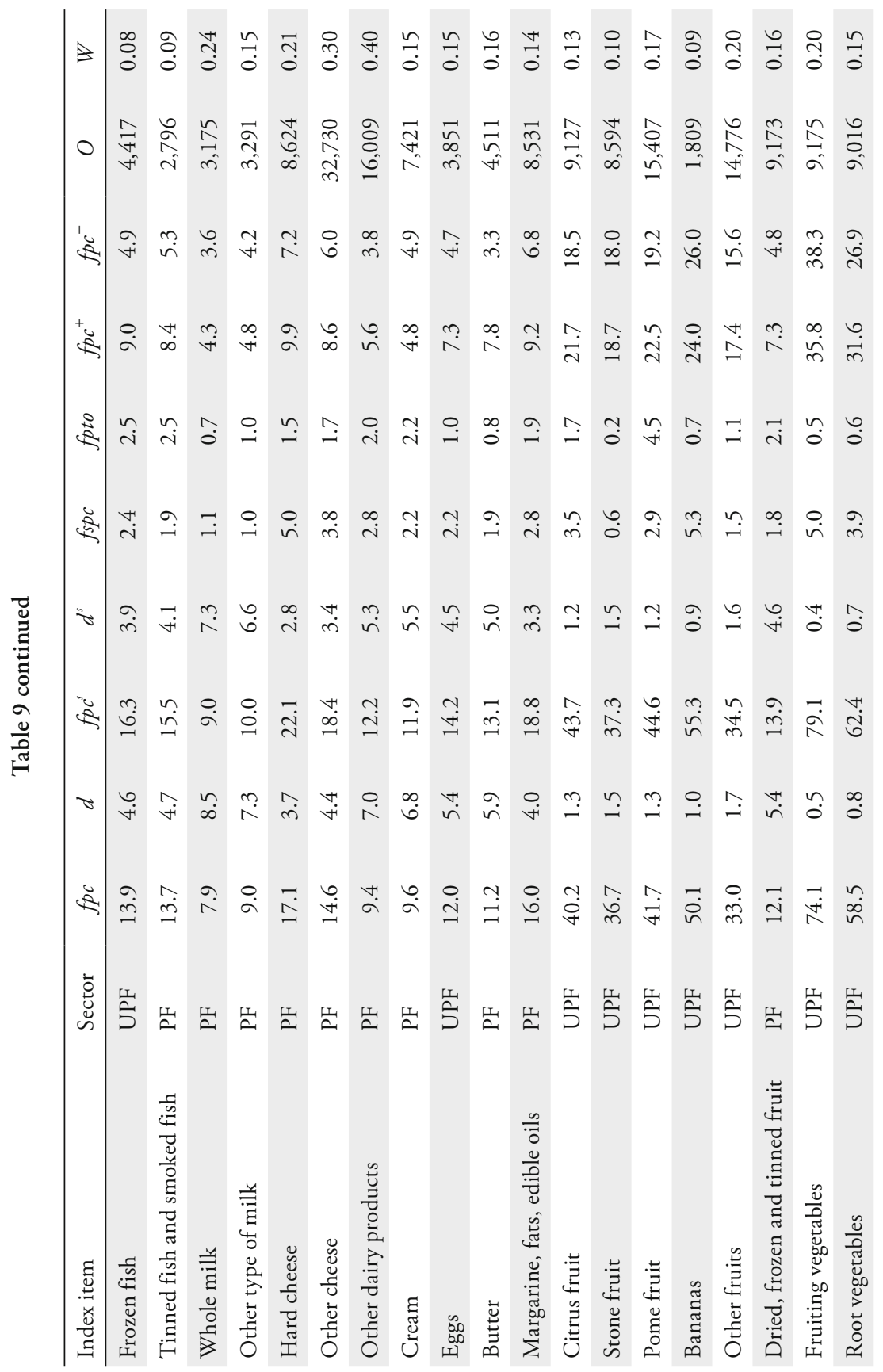




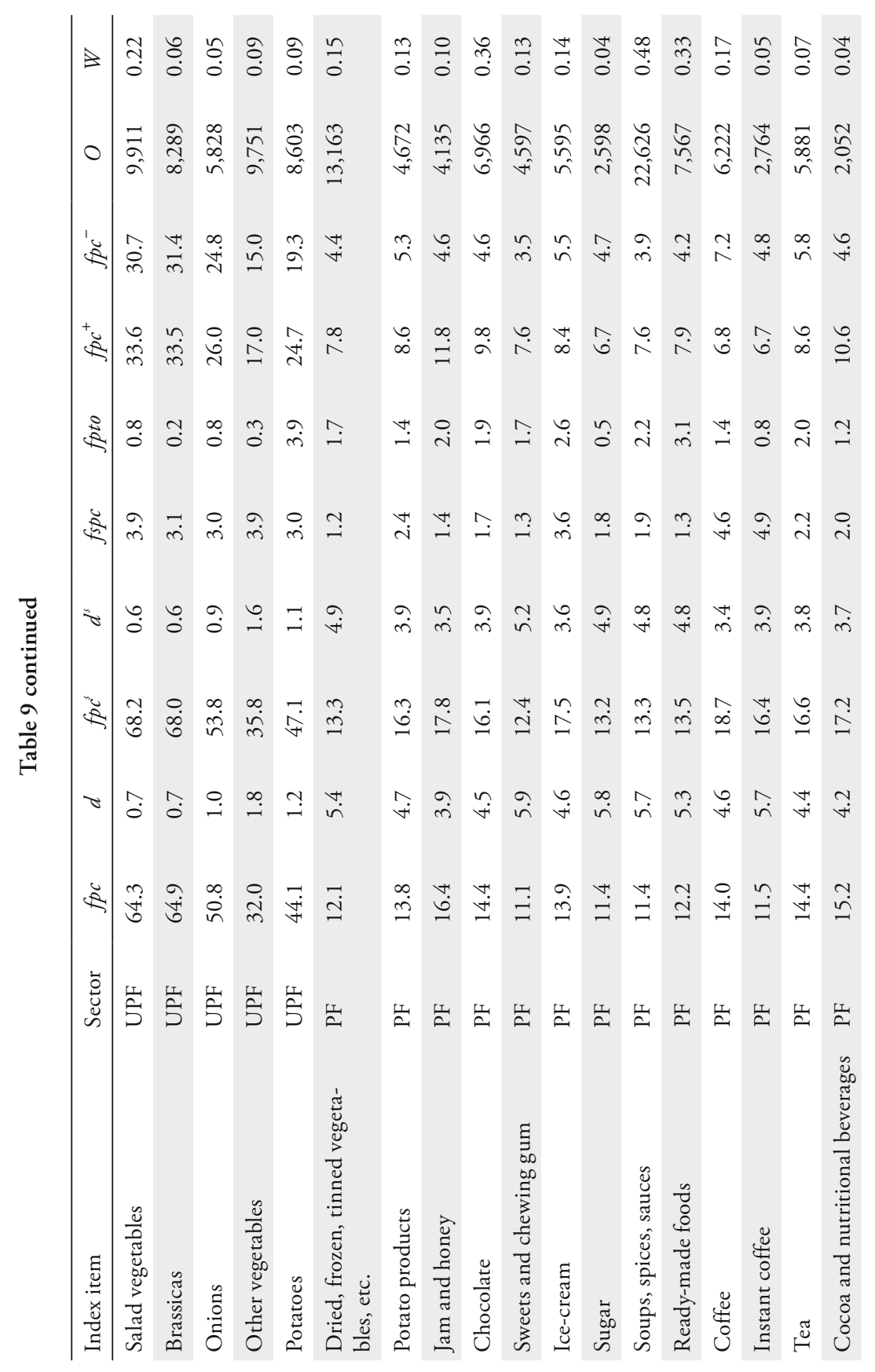




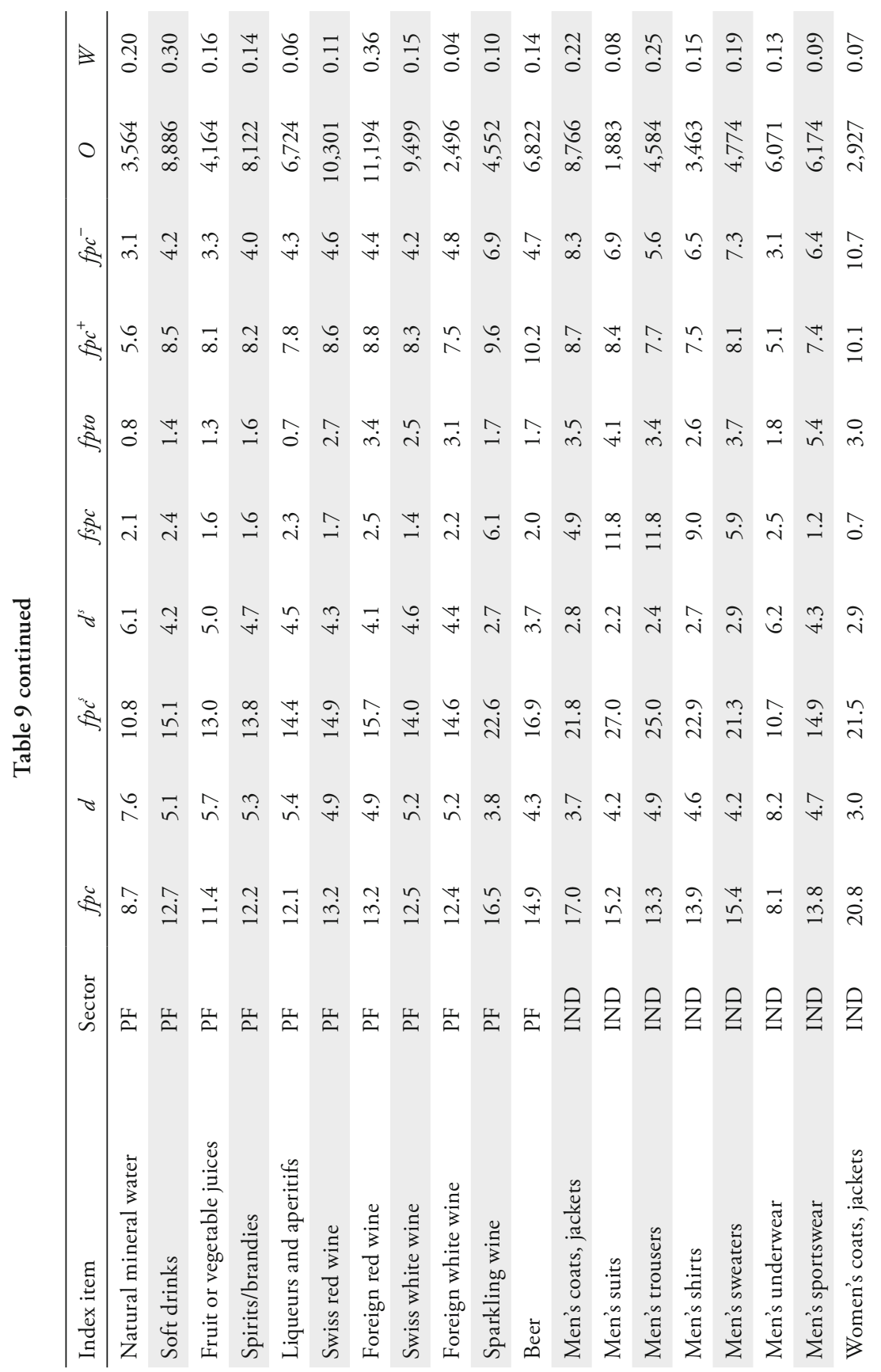




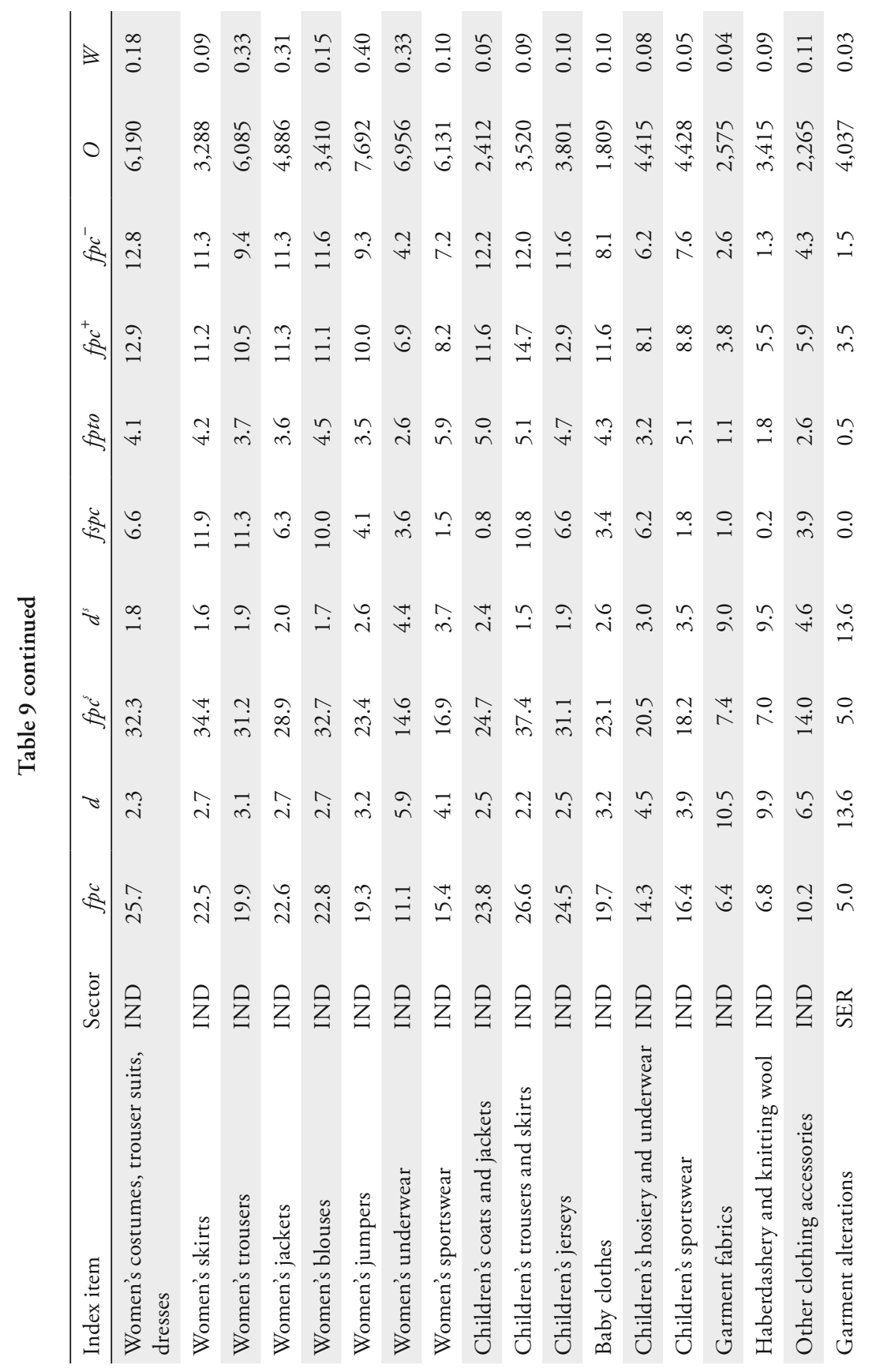




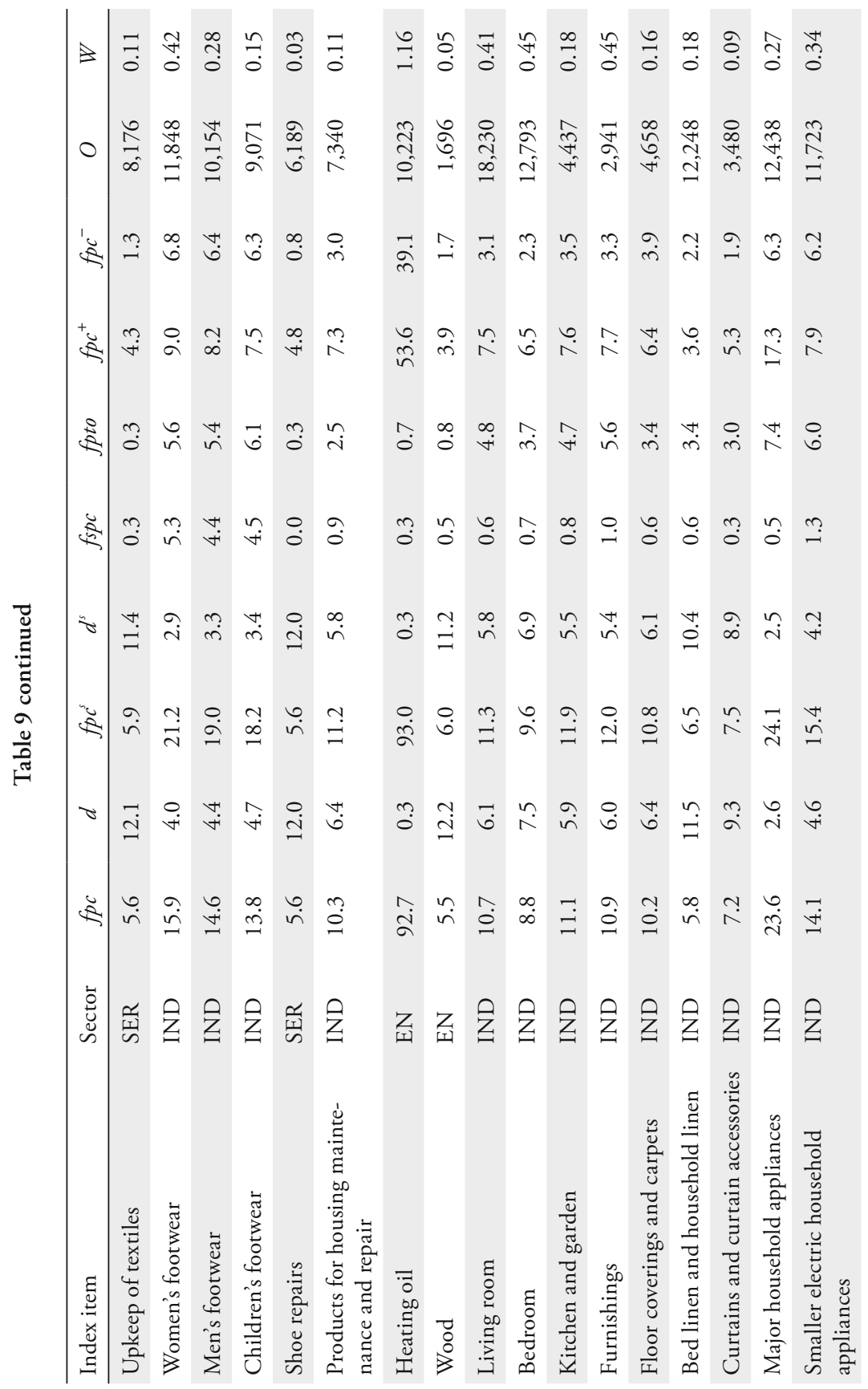




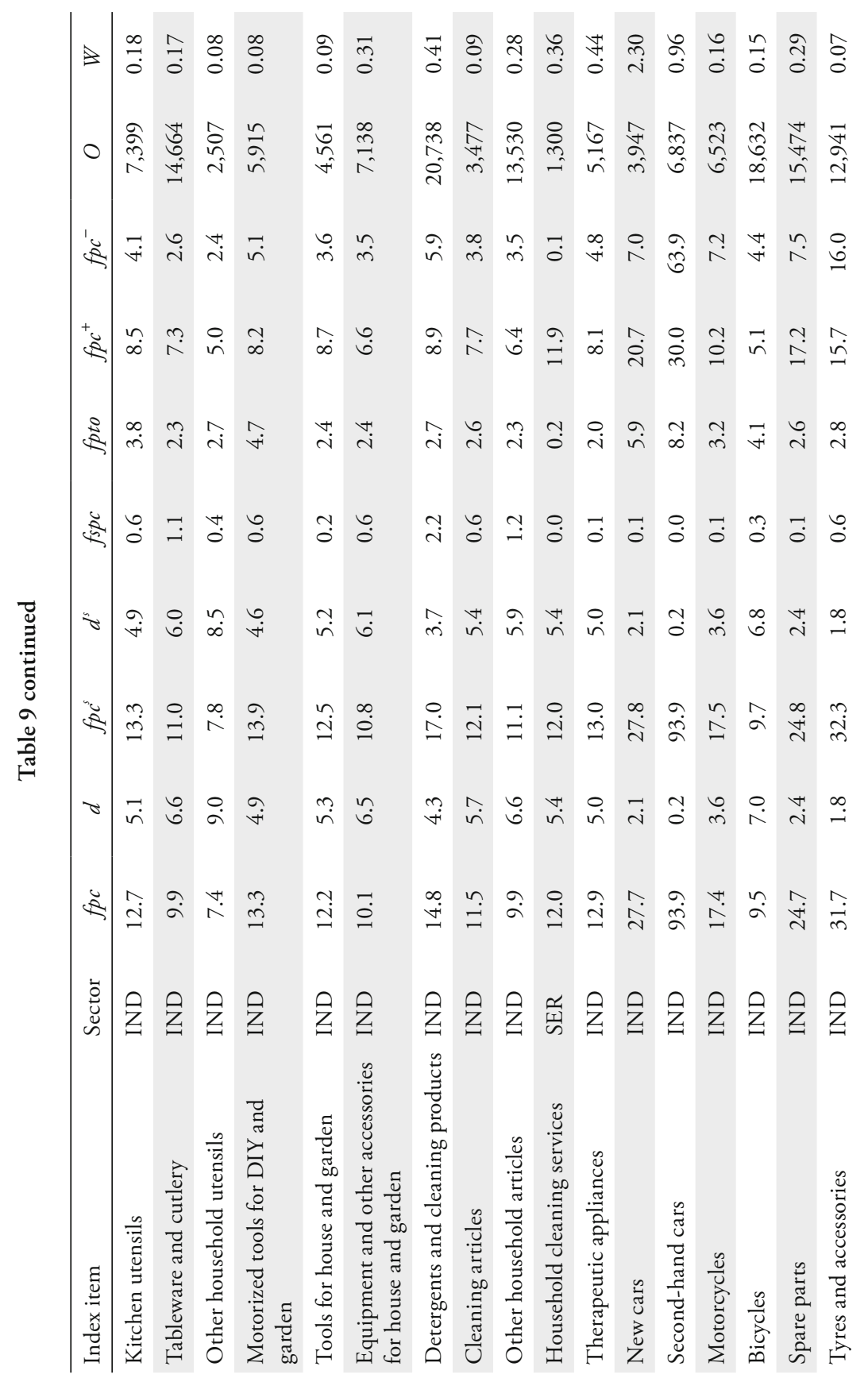




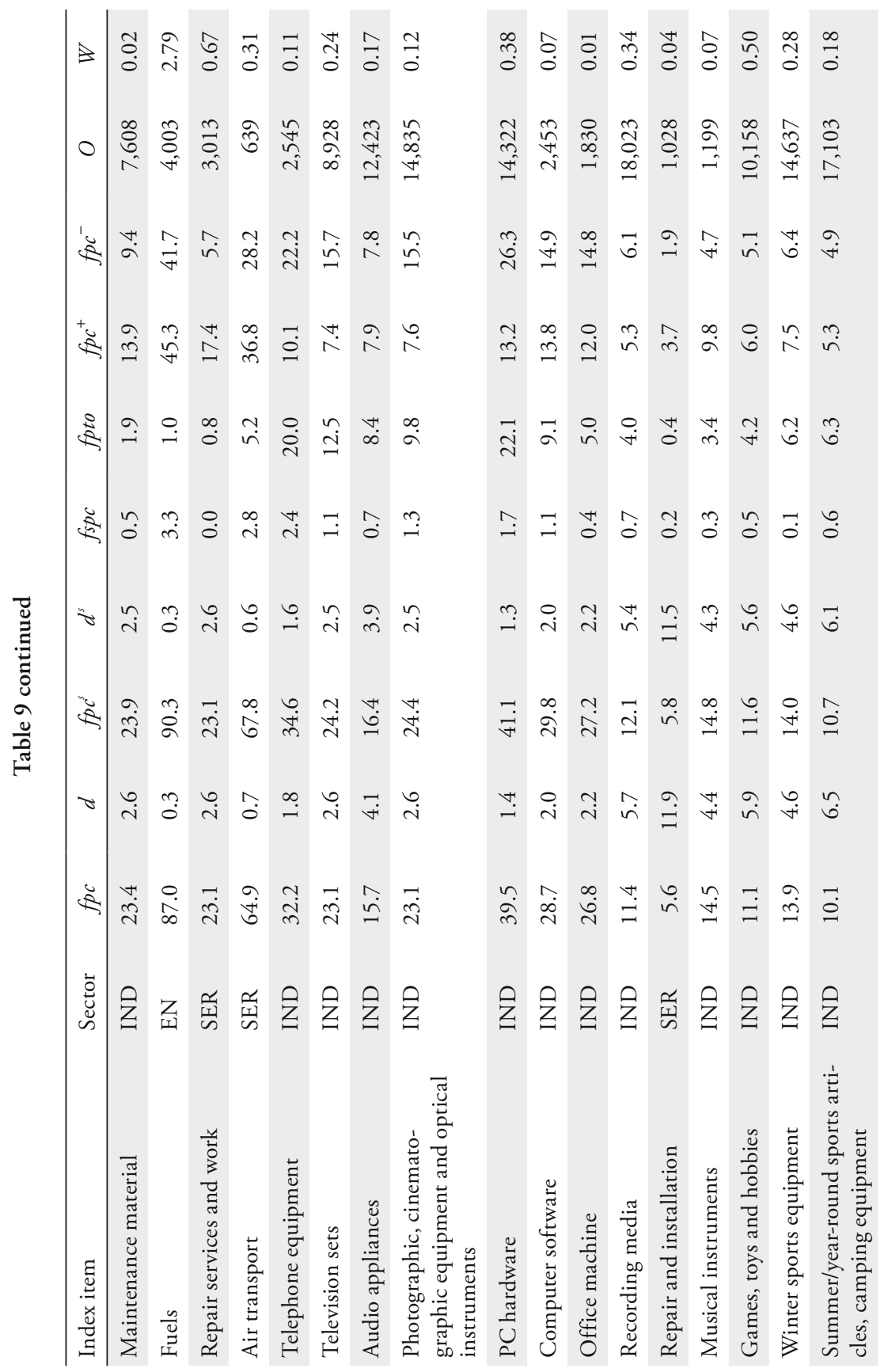




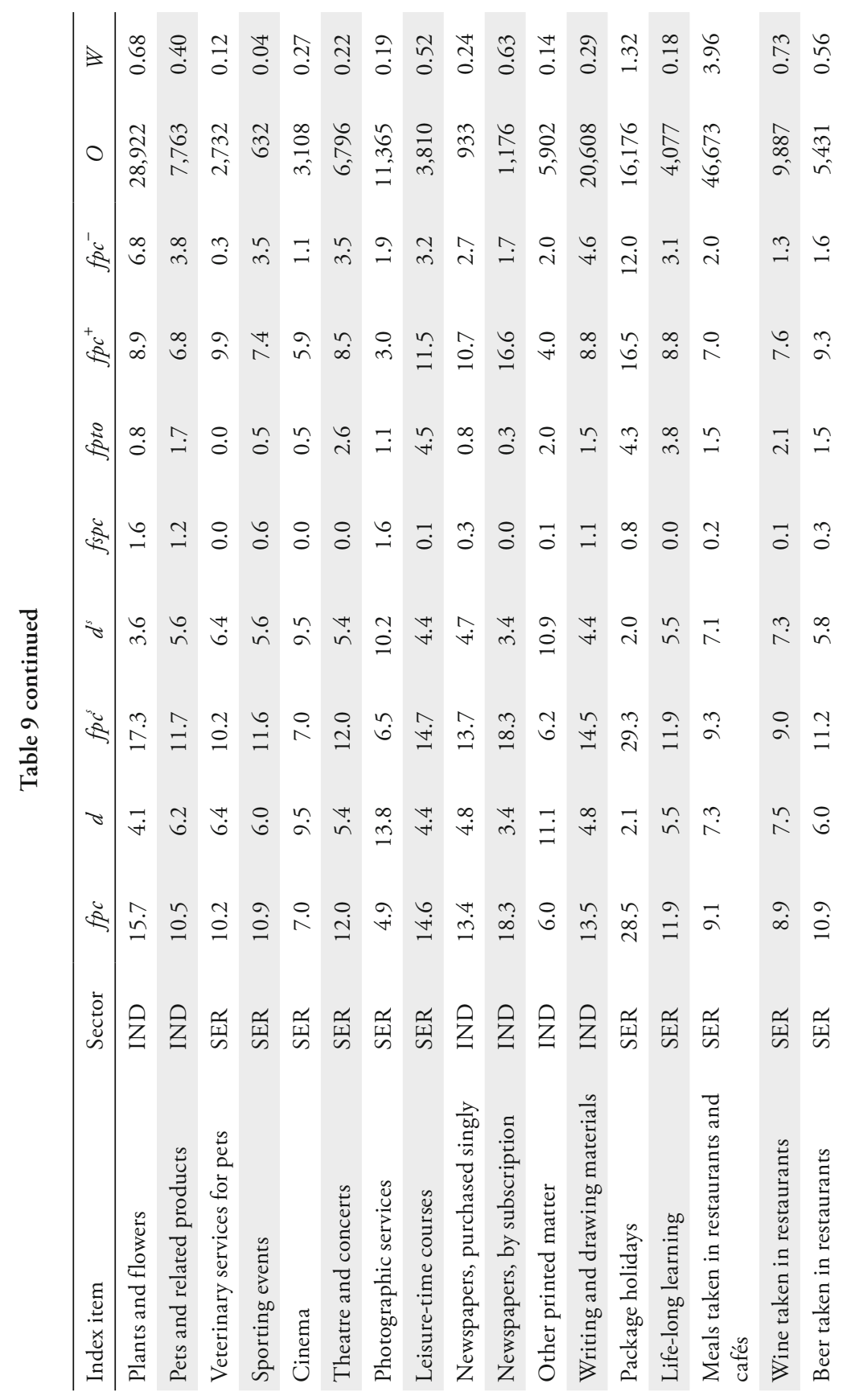




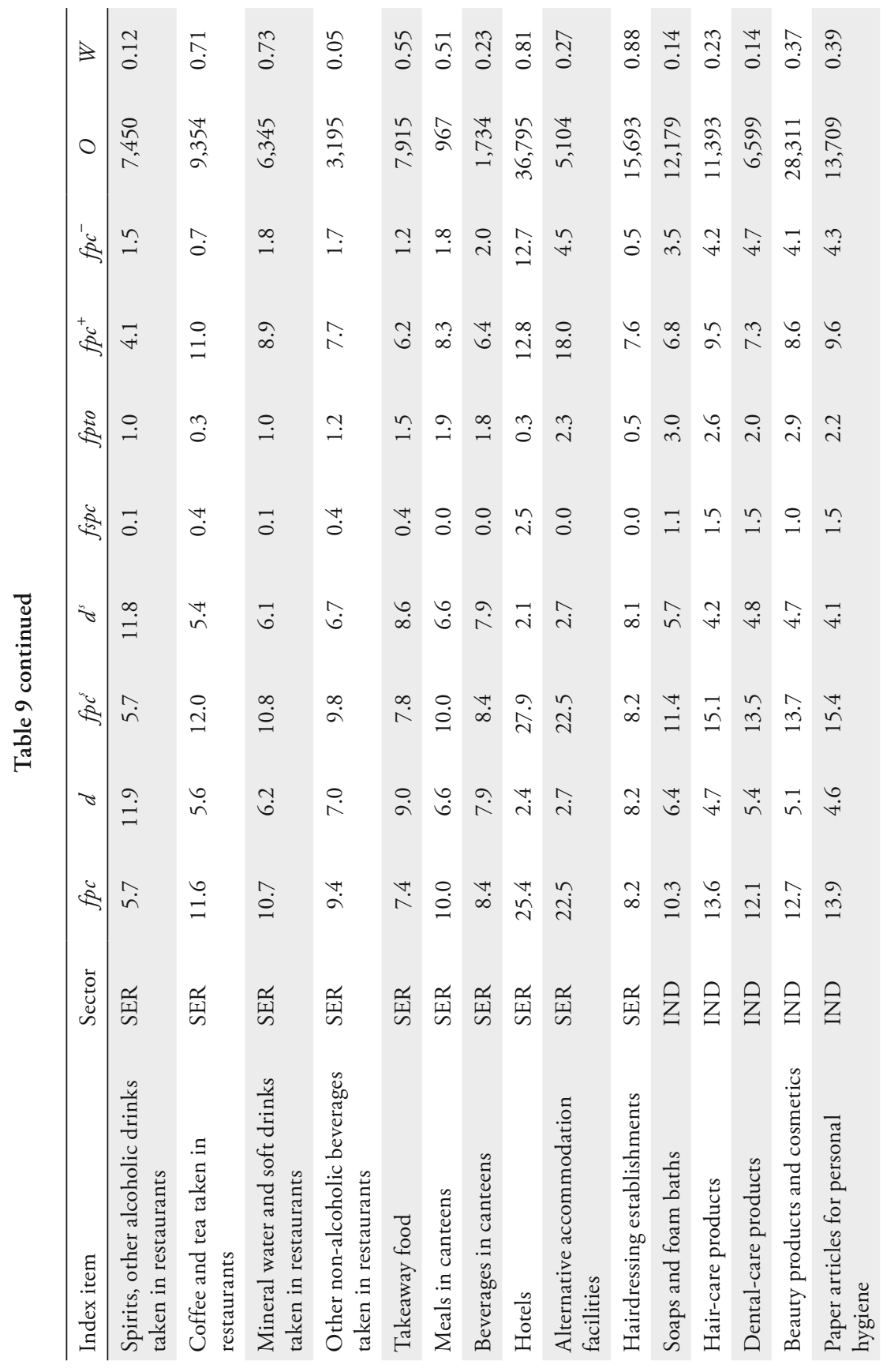




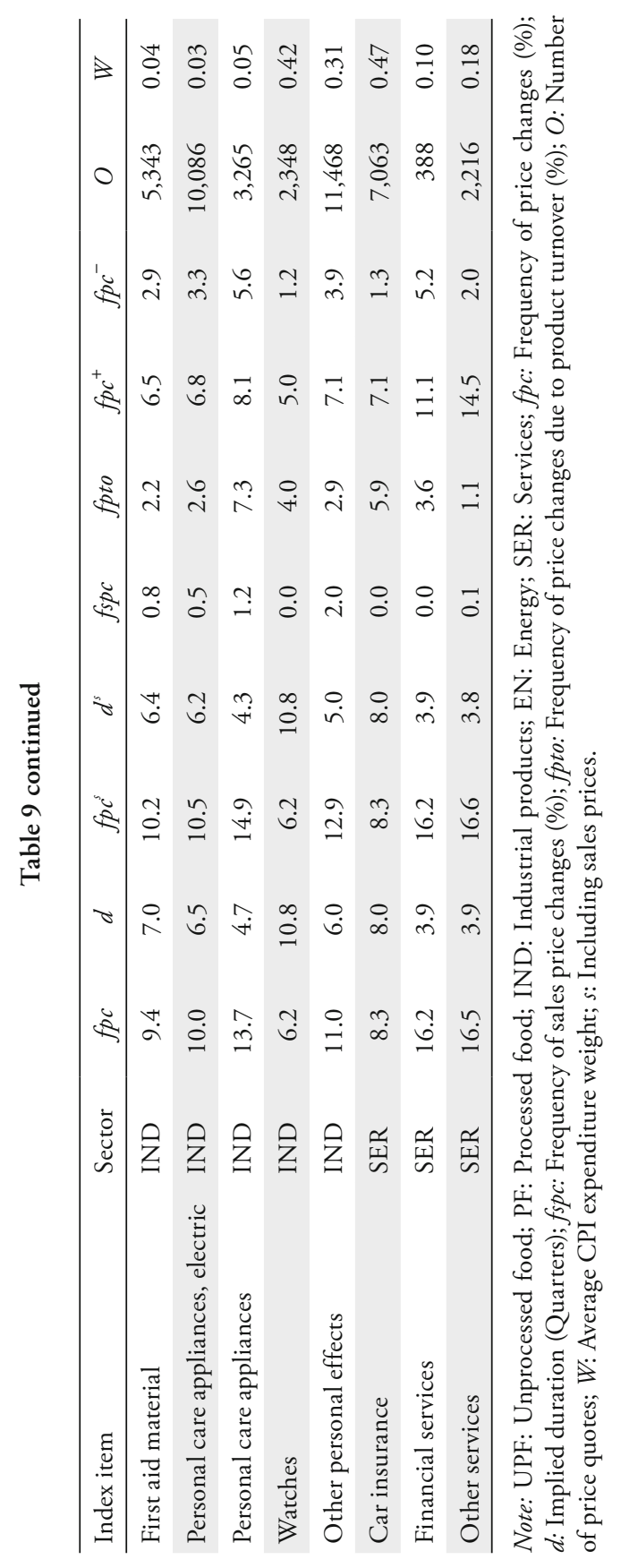


Table 10: Statistics across Index Items (Q1 2000-Q4 2005)

\begin{tabular}{|c|c|c|c|c|c|}
\hline Index item & Sector & Size & $\mathrm{Size}^{+}$ & $S_{i z e^{-}}$ & Sizes \\
\hline Rice & $\mathrm{PF}$ & 10.8 & 11.0 & 10.6 & 17.0 \\
\hline Flour & $\mathrm{PF}$ & 10.9 & 10.0 & 11.6 & 13.8 \\
\hline Bread & $\mathrm{PF}$ & 7.1 & 6.5 & 9.2 & 9.6 \\
\hline Small baked goods & $\mathrm{PF}$ & 11.8 & 11.7 & 12.3 & 13.4 \\
\hline Viennese pastries, pastry products & $\mathrm{PF}$ & 11.8 & 11.4 & 13.8 & 16.5 \\
\hline Biscuit/rusk products & $\mathrm{PF}$ & 10.9 & 10.6 & 11.2 & 16.1 \\
\hline Pasta & PF & 12.9 & 12.7 & 13.2 & 20.0 \\
\hline Other cereal products & $\mathrm{PF}$ & 10.8 & 10.6 & 11.0 & 17.0 \\
\hline Beef & UPF & 12.5 & 12.5 & 12.5 & 13.3 \\
\hline Veal & UPF & 9.5 & 9.9 & 9.0 & 9.9 \\
\hline Pork & UPF & 13.9 & 14.7 & 12.8 & 14.2 \\
\hline Lamb & UPF & 12.5 & 12.5 & 12.5 & 14.3 \\
\hline Poultry & UPF & 14.8 & 14.0 & 16.6 & 17.9 \\
\hline Other meat & UPF & 14.2 & 14.7 & 13.5 & 19.7 \\
\hline Sausages & $\mathrm{PF}$ & 12.8 & 12.1 & 14.9 & 15.8 \\
\hline Cooked meat & $\mathrm{PF}$ & 11.7 & 11.5 & 12.2 & 13.5 \\
\hline Processed meat & PF & 12.4 & 11.9 & 13.4 & 15.1 \\
\hline Fresh fish & UPF & 14.9 & 16.5 & 12.8 & 16.9 \\
\hline Frozen fish & UPF & 10.6 & 10.1 & 11.5 & 12.1 \\
\hline Tinned fish and smoked fish & $\mathrm{PF}$ & 12.3 & 12.4 & 12.2 & 13.6 \\
\hline Whole milk & $\mathrm{PF}$ & 6.7 & 6.1 & 7.4 & 8.7 \\
\hline Other type of milk & $\mathrm{PF}$ & 6.7 & 6.0 & 7.5 & 7.5 \\
\hline Hard cheese & $\mathrm{PF}$ & 11.8 & 11.9 & 11.8 & 14.7 \\
\hline Other cheese & PF & 10.5 & 10.0 & 11.2 & 13.5 \\
\hline Other dairy products & $\mathrm{PF}$ & 12.1 & 11.6 & 12.9 & 17.3 \\
\hline Cream & $\mathrm{PF}$ & 10.8 & 10.3 & 11.2 & 12.8 \\
\hline Eggs & UPF & 9.6 & 9.4 & 9.9 & 12.8 \\
\hline Butter & $\mathrm{PF}$ & 6.4 & 6.5 & 6.1 & 7.8 \\
\hline Margarine, fats, edible oils & $\mathrm{PF}$ & 9.4 & 9.5 & 9.2 & 12.5 \\
\hline Citrus fruit & UPF & 26.0 & 29.5 & 21.7 & 25.9 \\
\hline
\end{tabular}


Table 10 continued

\begin{tabular}{|c|c|c|c|c|c|}
\hline Index item & Sector & Size & $\mathrm{Size}^{+}$ & Size & Sizes \\
\hline Stone fruit & UPF & 42.6 & 55.9 & 29.9 & 43.4 \\
\hline Pome fruit & UPF & 19.9 & 21.8 & 17.6 & 20.1 \\
\hline Bananas & UPF & 15.7 & 18.9 & 12.8 & 16.6 \\
\hline Other fruits & UPF & 31.2 & 37.6 & 24.2 & 31.9 \\
\hline Dried, frozen and tinned fruit & $\mathrm{PF}$ & 12.0 & 12.1 & 11.7 & 14.2 \\
\hline Fruiting vegetables & UPF & 28.5 & 35.2 & 22.3 & 28.3 \\
\hline Root vegetables & UPF & 24.0 & 27.1 & 20.3 & 24.0 \\
\hline Salad vegetables & UPF & 30.5 & 35.6 & 24.9 & 31.1 \\
\hline Brassicas & UPF & 30.5 & 37.1 & 23.4 & 30.3 \\
\hline Onions & UPF & 29.0 & 35.0 & 22.7 & 28.7 \\
\hline Other vegetables & UPF & 22.1 & 24.9 & 19.1 & 22.1 \\
\hline Potatoes & UPF & 23.5 & 25.9 & 20.6 & 23.9 \\
\hline $\begin{array}{l}\text { Dried, frozen, tinned vegetables, } \\
\text { etc. }\end{array}$ & PF & 10.2 & 9.6 & 11.3 & 11.7 \\
\hline Potato products & $\mathrm{PF}$ & 10.8 & 10.3 & 11.8 & 12.7 \\
\hline Jam and honey & PF & 9.0 & 8.8 & 9.6 & 10.4 \\
\hline Chocolate & $\mathrm{PF}$ & 9.5 & 8.9 & 10.9 & 14.2 \\
\hline Sweets and chewing gum & $\mathrm{PF}$ & 12.4 & 11.7 & 13.7 & 21.1 \\
\hline Ice-cream & PF & 12.2 & 11.4 & 13.5 & 20.5 \\
\hline Sugar & $\mathrm{PF}$ & 8.6 & 8.3 & 8.9 & 12.9 \\
\hline Soups, spices, sauces & $\mathrm{PF}$ & 10.4 & 10.1 & 11.0 & 12.9 \\
\hline Ready-made foods & PF & 10.8 & 9.8 & 12.6 & 12.9 \\
\hline Coffee & $\mathrm{PF}$ & 11.0 & 12.1 & 10.1 & 14.3 \\
\hline Instant coffee & PF & 8.0 & 7.7 & 8.3 & 11.4 \\
\hline Tea & $\mathrm{PF}$ & 12.7 & 12.8 & 12.4 & 19.4 \\
\hline Cocoa and nutritional beverages & $\mathrm{PF}$ & 7.0 & 6.1 & 9.4 & 9.2 \\
\hline Natural mineral water & $\mathrm{PF}$ & 11.1 & 10.7 & 12.0 & 14.6 \\
\hline Soft drinks & $\mathrm{PF}$ & 10.3 & 9.7 & 11.5 & 13.2 \\
\hline Fruit or vegetable juices & PF & 8.8 & 7.9 & 11.2 & 13.7 \\
\hline Spirits/brandies & PF & 6.3 & 6.2 & 6.7 & 9.9 \\
\hline Liqueurs and aperitifs & PF & 6.1 & 5.8 & 6.6 & 10.0 \\
\hline
\end{tabular}


Table 10 continued

\begin{tabular}{|c|c|c|c|c|c|}
\hline Index item & Sector & Size & $\mathrm{Size}^{+}$ & $\mathrm{Size}^{-}$ & Size \\
\hline Swiss red wine & $\mathrm{PF}$ & 8.3 & 7.5 & 9.9 & 11.6 \\
\hline Foreign red wine & $\mathrm{PF}$ & 10.5 & 9.9 & 11.7 & 17.5 \\
\hline Swiss white wine & PF & 8.2 & 7.5 & 9.8 & 12.0 \\
\hline Foreign white wine & PF & 10.3 & 9.1 & 12.1 & 17.0 \\
\hline Sparkling wine & $\mathrm{PF}$ & 8.3 & 7.7 & 9.1 & 11.7 \\
\hline Beer & PF & 9.4 & 9.0 & 10.2 & 12.7 \\
\hline Men's coats, jackets & IND & 31.4 & 37.6 & 25.0 & 37.1 \\
\hline Men's suits & IND & 26.5 & 29.9 & 22.4 & 32.4 \\
\hline Men's trousers & IND & 30.4 & 35.3 & 24.1 & 42.8 \\
\hline Men's shirts & IND & 31.8 & 35.9 & 27.1 & 42.8 \\
\hline Men's sweaters & IND & 35.3 & 42.2 & 27.6 & 43.1 \\
\hline Men's underwear & IND & 17.6 & 17.0 & 18.6 & 27.0 \\
\hline Men's sportswear & IND & 21.0 & 22.6 & 19.2 & 28.0 \\
\hline Women's coats, jackets & IND & 35.9 & 43.2 & 28.9 & 36.5 \\
\hline $\begin{array}{l}\text { Women's costumes, trouser suits, } \\
\text { dresses }\end{array}$ & IND & 37.1 & 44.8 & 29.2 & 40.9 \\
\hline Women's skirts & IND & 38.0 & 46.3 & 29.5 & 44.3 \\
\hline Women's trousers & IND & 34.5 & 42.0 & 26.2 & 43.6 \\
\hline Women's jackets & IND & 37.2 & 45.9 & 28.0 & 42.3 \\
\hline Women's blouses & IND & 39.0 & 48.8 & 29.8 & 45.7 \\
\hline Women's jumpers & IND & 39.3 & 47.7 & 30.6 & 43.2 \\
\hline Women's underwear & IND & 16.6 & 17.9 & 14.5 & 31.2 \\
\hline Women's sportswear & IND & 22.3 & 24.2 & 20.3 & 29.0 \\
\hline Children's coats and jackets & IND & 36.2 & 43.6 & 29.1 & 35.9 \\
\hline Children's trousers and skirts & IND & 37.6 & 45.4 & 28.2 & 43.5 \\
\hline Children's jerseys & IND & 36.3 & 44.0 & 27.8 & 42.1 \\
\hline Baby clothes & IND & 28.3 & 31.4 & 24.0 & 29.0 \\
\hline Children's hosiery and underwear & IND & 21.5 & 23.0 & 19.7 & 30.5 \\
\hline Children's sportswear & IND & 26.4 & 29.9 & 22.5 & 30.2 \\
\hline Garment fabrics & IND & 16.7 & 14.7 & 19.4 & 22.5 \\
\hline Haberdashery and knitting wool & IND & 9.3 & 7.9 & 16.7 & 13.8 \\
\hline
\end{tabular}


Table 10 continued

\begin{tabular}{|c|c|c|c|c|c|}
\hline Index item & Sector & Size & Size $^{+}$ & Size $e^{-}$ & $S i z e^{s}$ \\
\hline Other clothing accessories & IND & 22.7 & 24.7 & 20.0 & 29.3 \\
\hline Garment alterations & SER & 17.0 & 17.6 & 15.4 & 20.0 \\
\hline Upkeep of textiles & SER & 11.2 & 11.3 & 10.9 & 14.0 \\
\hline Women's footwear & IND & 23.5 & 24.6 & 21.9 & 27.5 \\
\hline Men's footwear & IND & 23.3 & 25.6 & 20.4 & 26.6 \\
\hline Children's footwear & IND & 22.1 & 24.1 & 19.8 & 25.6 \\
\hline Shoe repairs & SER & 7.4 & 7.6 & 6.5 & 9.7 \\
\hline $\begin{array}{l}\text { Products for housing maintenance } \\
\text { and repair }\end{array}$ & IND & 10.3 & 9.6 & 12.1 & 15.5 \\
\hline Heating oil & EN & 12.0 & 13.4 & 10.2 & 12.0 \\
\hline Wood & EN & 11.7 & 10.7 & 14.5 & 11.1 \\
\hline Living room & IND & 8.0 & 7.2 & 10.0 & 10.5 \\
\hline Bedroom & IND & 7.9 & 6.6 & 11.7 & 10.0 \\
\hline Kitchen and garden & IND & 10.2 & 9.2 & 12.6 & 13.1 \\
\hline Furnishings & IND & 10.5 & 8.6 & 15.4 & 16.5 \\
\hline Floor coverings and carpets & IND & 13.3 & 11.9 & 15.7 & 15.8 \\
\hline Bed linen and household linen & IND & 14.4 & 13.6 & 15.6 & 16.1 \\
\hline Curtains and curtain accessories & IND & 8.7 & 7.6 & 11.8 & 8.9 \\
\hline Major household appliances & IND & 5.5 & 4.4 & 8.4 & 5.6 \\
\hline $\begin{array}{l}\text { Smaller electric household } \\
\text { appliances }\end{array}$ & IND & 9.9 & 8.9 & 11.2 & 11.4 \\
\hline Kitchen utensils & IND & 9.4 & 8.6 & 11.2 & 17.5 \\
\hline Tableware and cutlery & IND & 8.6 & 7.7 & 11.3 & 16.7 \\
\hline Other household utensils & IND & 12.3 & 11.5 & 14.0 & 14.2 \\
\hline $\begin{array}{l}\text { Motorized tools for DIY and } \\
\text { garden }\end{array}$ & IND & 10.3 & 9.4 & 11.8 & 12.0 \\
\hline Tools for house and garden & IND & 8.1 & 7.5 & 9.6 & 17.0 \\
\hline $\begin{array}{l}\text { Equipment and other accessories } \\
\text { for house and garden }\end{array}$ & IND & 9.9 & 9.5 & 10.8 & 14.7 \\
\hline Detergents and cleaning products & IND & 11.8 & 11.9 & 11.7 & 15.4 \\
\hline Cleaning articles & IND & 12.9 & 13.1 & 12.6 & 17.1 \\
\hline Other household articles & IND & 13.2 & 13.1 & 13.5 & 19.5 \\
\hline
\end{tabular}


Table 10 continued

\begin{tabular}{|c|c|c|c|c|c|}
\hline Index item & Sector & Size & $\mathrm{Size}^{+}$ & Size $e^{-}$ & Sizes \\
\hline Household cleaning services & SER & 0.8 & 0.8 & & 0.8 \\
\hline Therapeutic appliances & IND & 6.8 & 5.7 & 8.8 & 7.8 \\
\hline New cars & IND & 2.4 & 1.9 & 4.5 & 12.1 \\
\hline Second-hand cars & IND & 2.5 & 3.5 & 2.0 & 2.4 \\
\hline Motorcycles & IND & 4.6 & 3.1 & 6.8 & 13.8 \\
\hline Bicycles & IND & 12.0 & 13.7 & 10.1 & 22.7 \\
\hline Spare parts & IND & 5.4 & 4.8 & 6.7 & 9.4 \\
\hline Tyres and accessories & IND & 6.3 & 5.5 & 7.1 & 7.1 \\
\hline Maintenance material & IND & 6.8 & 5.9 & 8.0 & 7.7 \\
\hline Fuels & EN & 4.8 & 5.5 & 4.0 & 4.9 \\
\hline Repair services and work & SER & 4.0 & 4.0 & 4.0 & 4.1 \\
\hline Air transport & SER & 29.0 & 33.7 & 23.2 & 29.2 \\
\hline Telephone equipment & IND & 15.7 & 16.9 & 15.1 & 18.3 \\
\hline Television sets & IND & 13.9 & 11.5 & 15.1 & 16.1 \\
\hline Audio appliances & IND & 12.7 & 11.7 & 13.8 & 19.4 \\
\hline $\begin{array}{l}\text { Photographic, cinematographic } \\
\text { equipment and optical instruments }\end{array}$ & IND & 12.8 & 12.2 & 13.1 & 14.6 \\
\hline PC hardware & IND & 11.4 & 10.1 & 12.1 & 13.4 \\
\hline Computer software & IND & 8.4 & 8.5 & 8.4 & 9.4 \\
\hline Office machine & IND & 8.4 & 9.3 & 7.6 & 11.8 \\
\hline Recording media & IND & 14.3 & 13.5 & 15.1 & 19.1 \\
\hline Repair and installation & SER & 14.7 & 14.6 & 14.9 & 14.6 \\
\hline Musical instruments & IND & 7.3 & 6.3 & 9.4 & 7.2 \\
\hline Games, toys and hobbies & IND & 11.8 & 9.4 & 14.8 & 22.4 \\
\hline Winter sports equipment & IND & 18.2 & 19.2 & 17.1 & 24.7 \\
\hline $\begin{array}{l}\text { Summer/year-round sports articles, } \\
\text { camping equipment }\end{array}$ & IND & 15.7 & 16.5 & 14.9 & 26.8 \\
\hline Plants and flowers & IND & 19.2 & 20.4 & 17.6 & 22.2 \\
\hline Pets and related products & IND & 8.7 & 8.3 & 9.5 & 18.5 \\
\hline Veterinary services for pets & SER & 5.0 & 5.1 & 2.7 & 5.0 \\
\hline Sporting events & SER & 28.2 & 28.6 & 24.8 & 42.6 \\
\hline
\end{tabular}


Table 10 continued

\begin{tabular}{|c|c|c|c|c|c|}
\hline Index item & Sector & Size & $\mathrm{Size}^{+}$ & $S_{i z e^{-}}$ & $S i z e^{s}$ \\
\hline Cinema & SER & 9.5 & 9.6 & 8.9 & 10.1 \\
\hline Theatre and concerts & SER & 8.1 & 8.3 & 7.7 & 8.2 \\
\hline Photographic services & SER & 25.6 & 28.1 & 21.9 & 38.8 \\
\hline Leisure-time courses & SER & 8.0 & 7.8 & 10.1 & 11.7 \\
\hline Newspapers, purchased singly & IND & 10.0 & 10.7 & 6.1 & 18.4 \\
\hline Newspapers, by subscription & IND & 3.2 & 3.2 & 3.8 & 11.8 \\
\hline Other printed matter & IND & 12.6 & 13.0 & 11.8 & 12.5 \\
\hline Writing and drawing materials & IND & 9.3 & 8.6 & 10.7 & 16.8 \\
\hline Package holidays & SER & 8.4 & 8.2 & 8.7 & 14.3 \\
\hline Life-long learning & SER & 8.7 & 8.5 & 9.6 & 10.7 \\
\hline $\begin{array}{l}\text { Meals taken in restaurants and } \\
\text { cafés }\end{array}$ & SER & 8.0 & 7.8 & 8.6 & 11.1 \\
\hline Wine taken in restaurants & SER & 7.4 & 7.3 & 8.0 & 7.9 \\
\hline Beer taken in restaurants & SER & 6.4 & 6.0 & 8.7 & 7.4 \\
\hline $\begin{array}{l}\text { Spirits, other alcoholic drinks } \\
\text { taken in restaurants }\end{array}$ & SER & 12.4 & 12.3 & 12.9 & 14.8 \\
\hline Coffee and tea taken in restaurants & SER & 5.1 & 5.0 & 6.9 & 5.6 \\
\hline $\begin{array}{l}\text { Mineral water and soft drinks } \\
\text { taken in restaurants }\end{array}$ & SER & 6.9 & 6.3 & 10.4 & 7.8 \\
\hline $\begin{array}{l}\text { Other non-alcoholic beverages } \\
\text { taken in restaurants }\end{array}$ & SER & 7.4 & 6.8 & 10.3 & 8.8 \\
\hline Takeaway food & SER & 9.7 & 9.2 & 12.2 & 10.2 \\
\hline Meals in canteens & SER & 8.5 & 8.4 & 9.5 & 9.0 \\
\hline Beverages in canteens & SER & 13.0 & 12.6 & 14.5 & 13.1 \\
\hline Hotels & SER & 25.9 & 31.9 & 19.9 & 25.5 \\
\hline $\begin{array}{l}\text { Alternative accommodation } \\
\text { facilities }\end{array}$ & SER & 5.2 & 4.5 & 9.4 & 14.6 \\
\hline Hairdressing establishments & SER & 6.4 & 6.3 & 8.8 & 8.0 \\
\hline Soaps and foam baths & IND & 9.7 & 9.3 & 10.4 & 17.4 \\
\hline Hair-care products & IND & 9.6 & 8.7 & 11.8 & 14.8 \\
\hline Dental-care products & IND & 9.4 & 8.5 & 10.9 & 12.9 \\
\hline Beauty products and cosmetics & IND & 9.4 & 8.8 & 10.8 & 16.1 \\
\hline
\end{tabular}


Table 10 continued

\begin{tabular}{llrrrc}
\hline Index item & Sector & Size & Size $^{+}$ & Size $^{-}$ & Size $^{s}$ \\
\hline Paper articles for personal hygiene & IND & 10.4 & 9.5 & 12.5 & 13.7 \\
First aid material & IND & 7.2 & 7.2 & 7.4 & 11.6 \\
Personal care appliances, electric & IND & 11.2 & 10.6 & 12.5 & 20.0 \\
Personal care appliances & IND & 10.7 & 9.4 & 12.5 & 12.0 \\
Watches & IND & 9.2 & 8.8 & 10.6 & 8.6 \\
Other personal effects & IND & 14.1 & 13.5 & 15.3 & 29.4 \\
Car insurance & SER & 7.6 & 7.6 & 7.4 & 7.6 \\
Financial services & SER & 26.8 & 32.1 & 12.7 & 26.8 \\
Other services & SER & 4.1 & 3.7 & 9.9 & 4.1 \\
\hline
\end{tabular}

Note: UPF: Unprocessed food; PF: Processed food; IND: Industrial products; EN: Energy; SER: Services; Size: Size of price changes (\%); s: Including sales prices.

\section{References}

Altissimo, Filippo, Michael Ehrmann, and Frank Smets (2006), "Inflation Persistence and Price-Setting Behaviour in the Euro Area - A Summary of the IPN Evidence,” Occasional Paper Series 46, European Central Bank.

Arellano, Manuel (1987), "Computing Robust Standard Errors for WithinGroups Estimators," Oxford Bulletin of Economics and Statistics 49 (4), pp. 431-434.

Bils, Mark, and Peter J. Klenow (2004), "Some Evidence on the Importance of Sticky Prices," Journal of Political Economy 112 (5), pp. 947-985.

Blinder, Alan S., Elie R. D. Canetti, David F. Lebow, and Jeremy B. Rudd (1998), Asking about Prices: A New Approach to Understanding Price Stickiness, Russel Sage Foundation, New York.

Calvo, Guillermo A. (1983), "Staggered Prices in a Utility-Maximizing Framework," Journal of Monetary Economics, 12 (3), pp.383-398.

Dhyne, Emmanuel, luis J. Àlvarez, Hervé Le Bihan, Giovanni Veronese, Daniel A. Dias, Johannes Hoffmann, Nicole Jonker, Patrick Lünnemann, Fabio Rumler, and Jouko Vilmunen (2006), "Price Changes in the Euro Area and the United States: Some Facts from Individual Consumer Price Data," Journal of Economic Perspectives 20 (2), pp. 171-192. 
Dias, Daniel A., Carlos R. Marques, and Joao M. C. Santos Silva (2007), "Time- or State-Dependent Price Setting Rules? Evidence from Micro Data," European Economic Review 51 (7), pp. 1589-1613.

Dotsey, Michael, Robert G. King, and Alexander L. Wolman (1999), "State-Dependent Pricing and the General Equilibrium Dynamics of Money and Output," Quarterly Journal of Economics 114 (2), pp. 655-690.

Fabiani, Silvia, Claudia Kwapil, Martine Druant, Ignacio Hernando, Bettina landau, Claire loupias, Fernando Martins, Thomas Y. Mathä, Roberto Sabbatini, Harald Stahl, and Ad Stokman (2005), "The Pricing Behaviour of Firms in the Euro Area - New Survey Evidence," Working Paper Series 535, European Central Bank.

Fehr, Ernst, and Lorenz Götte (2005), "Robustness and Real Consequences of Nominal Wage Rigidity," Journal of Monetary Economics 52 (4), pp. 779-804.

Fischer, Andreas, Matthias Lutz, and Manuel Wälti (2007), "Who Prices Locally? Survey Evidence of Swiss Exporters,” Working Paper 2007-16, Swiss National Bank.

Fougère, Denis, Hervé Le Bihan, and Patrick Sevestre (2007), "Heterogeneity in Consumer Price Stickiness: A Microeconometric Investigation," Journal of Business \& Economic Statistics 25, pp. 247-264.

FSO (1993), BFS aktuell - Der neue Landesindex der Konsumentenpreise: Mai $1993=100$, Federal Statistical Office.

- (2000), BFS aktuell - Der neue Landesindex der Konsumentenpreise: Mai $2000=100$, Federal Statistical Office.

- (2006), BFS aktuell - Der neue Landesindex der Konsumentenpreise: Dezember $2005=100$, Federal Statistical Office.

Gagnon, Etienne (2007), "Price Setting During Low and High Inflation: Evidence from Mexico," International Finance Discussion Paper 896, Board of Governors of the Federal Reserve System.

Götte, Lorenz, Rudolf Minsch, and Jean-Robert Tyran (2005), "Micro Evidence on the Adjustment of Sticky-Price Goods: It's How Often, Not How Much,” Discussion Paper 5364, C.E.P.R.

Klenow, Peter J., and Oleksiy Kryvtsov (2008), "State-Dependent or TimeDependent Pricing: Does it Matter for Recent U.S. Inflation?," Quarterly Journal of Economics 123 (3), pp. 863-904.

Nakamura, Emi, and Jón Steinsson (2008), "Five Facts About Prices: A Reevaluation of Menu Cost Models," Quarterly Journal of Economics 123 (4), pp. 1415-1464. 
Rupprecht, Sarah M. (2007), "When Do Firms Adjust Prices? Evidence from Micro Panel Data," Working Paper 160, KOF Swiss Economic Institute, ETH Zurich.

Taylor, John B. (1980), "Aggregate Dynamics and Staggered Contracts," The Journal of Political Economy 88 (1), pp. 1-23.

Wooldridge, Jeffrey M. (2005), "Fixed-Effects and Related Estimators for Correlated Random-Coefficient and Treatment-Effect Panel Data Models," The Review of Economics and Statistics 87 (2), pp. 385-390.

Zurlinden, Mathias (2007), “The Pricing Behaviour of Swiss Companies: Results of a Survey Conducted by the SNB Delegates for Regional Economic Relations," Quarterly Bulletin 2007-1, Swiss National Bank.

\section{SUMMARY}

This paper investigates price-setting behaviour of firms based on the individual price quotes underlying the Swiss consumer price index. The data set covers the years from 1993 to 2005. Six main findings emerge from the analysis. (i) Prices are sticky; the median duration amounts to 4.6 quarters. (ii) Price-setting behaviour is heterogeneous across sectors and outlet characteristics. (iii) Price changes are sizeable; the median absolute size amounts to $9.4 \%$. (iv) There is little evidence of downward price stickiness; almost half of all price changes are decreases. An exception is the service sector, however, where there is evidence of asymmetries in price-setting due to downward rigid wages. (v) Firms respond to expected cost shocks at the date of their occurrence; VAT rate changes do not lead to more price adjustments before they take effect. (vi) There is some evidence that firms adjust their behaviour according to the state of the economy; in particular, firms facing higher rates of inflation adjust prices more frequently. 